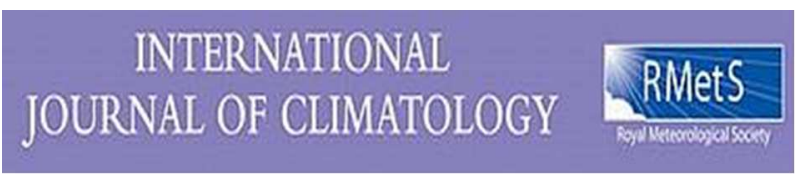

\title{
ENSO Influence on the Interannual Variability of the Red Sea Convergence Zone and Associated Rainfall
}

\begin{tabular}{|r|l|}
\hline Journal: & International Journal of Climatology \\
\hline Manuscript ID & JOC-16-0652.R1 \\
\hline Wiley - Manuscript type: & Research Article \\
\hline Complete List of Authors: & $\begin{aligned} \text { Dasari, Hari Prasad; King Abdullah University of Science and Technology, } \\
\text { Physical Sciences and Engineering Division } \\
\text { Langodan, Sabique; King Abdullah University of Science and Technology, } \\
\text { Physical Sciences and Engineering Division } \\
\text { Viswanadhapalli, Yesubabu; King Abdullah University of Science and } \\
\text { Technology, Physical Sciences and Engineering Division; National } \\
\text { Atmospheric Research Laboratory, Weather and Climate Research Group } \\
\text { Rao, V.; Instituto Nacional de Pesquisas Espaciais, Centro de Previsão de } \\
\text { Tempo e Estudos Climáticos } \\
\text { Papadopoulos, Vassilis; Hellenic Centre for Marine Research, Marine } \\
\text { Research Center } \\
\text { Hoteit, Ibrahim ; King Abdullah University of Science and Technology, } \\
\text { Physical Sciences and Engineering Division }\end{aligned}$ \\
\hline Keywords: & $\begin{array}{l}\text { Red Sea Convergence Zone, Red Sea Trough, ENSO, Rainfall, Moisture } \\
\text { Convergence }\end{array}$ \\
\hline
\end{tabular}


ENSO Influence on the Interannual Variability of the Red Sea Convergence Zone and Associated Rainfall

$4 \quad$ Hari Prasad Dasari ${ }^{1}$, Sabique Langodan ${ }^{1}$, Yesubabu Viswanadhapalli ${ }^{2}$, Brahmananda Rao 5 Vadlamudi ${ }^{3}$, Vassilis P. Papadopoulos ${ }^{4}$, and Ibrahim Hoteit ${ }^{1, *}$

1. King Abdullah University of Science and Technology (KAUST), Physical Sciences and Engineering Division, Thuwal, Saudi Arabia

2. National Atmospheric Research Laboratory, Gadanki, Andhra Pradesh, India

3. Centro de Previsão de Tempo e Estudos Climáticos (CPTECH), INPE, Brazil

4. Hellenic Centre for Marine Research, Anavissos, Greece

\section{*Corresponding author: Ibrahim.hoteit@kaust.edu.sa}

6

17

8

9

0

1

2

3

4

25

6

7


Abstract

The Red Sea Convergence Zone (RSCZ) is formed by opposite surface winds blowing

30

31

32

from northwest and southeast directions at around $18^{\circ}-19^{\circ} \mathrm{N}$ between October and January. A reverse-oriented, low-level monsoon trough at $850 \mathrm{hPa}$, known as the Red Sea Trough (RST), transfers moisture from the southern Red Sea to RSCZ. The positions of the RSCZ and RST and the intensity of the RST have been identified as important factors in modulating weather and climatic conditions across the Middle East. Here, we investigate the influence of the El Niño southern oscillation (ENSO) on the interannual variability of RSCZ, RST, and regional rainfall during winter months. Our results indicate that El Niño (warm ENSO phase) favors a shift of the RSCZ to the north and a strengthening of the RST in the same direction. Conversely, during November and December of La Niña periods (cold ENSO phase), the RSCZ shift to the south and the RST strengthens in the same direction. During El Niño periods, southeasterly wind speeds increase (20-30\%) over the southern Red Sea and northwesterly wind speeds decrease $(10-15 \%)$ over the northern Red Sea. Noticeable increases in the number of rainy days and the intensity of rain events are observed during El Niño phases. These increases are associated with colder than normal air intrusion at lower levels from the north combined with warm air intrusion from the south over the RSCZ. Our analysis suggests that during El Niño winters, warmer sea surface temperatures and higher convective instability over the Red Sea favor local storms conditions and increase rainfall over the Red Sea and adjoining regions.

Keywords: Red Sea Convergence Zone, Red Sea Trough, ENSO, Rainfall, Moisture Convergence 


\section{Introduction}

The elongated Red Sea acts as a channel that transports moisture between the

52 Mediterranean and Arabian Seas (Pedgley, 1966; Tsvieli and Zangvil, 2005), influencing the

53 weather and climate of the Middle East. During winter, between October and March, the

54 northern Red Sea experiences northwest winds blowing from the Mediterranean region, while

55 the southern Red Sea experiences southeasterly winds blowing from the Gulf of Aden. These

56 opposing wind streams meet at the center of the Red Sea (Fig. 1) to form the Red Sea

57 Convergence Zone (RSCZ, Pedgley, 1966, 1972, Abualnaja et al., 2015; Langodan et al., 2015).

58 This area is characterized by cloudy skies and drizzle in contrast with the typically clear weather

59 in the region. Converging winds in RSCZ funnel out to the west through a valley called the

60 Tokar Gap, an area spanning $\sim 50 \mathrm{~km}$ in width between the Sudanese coast and its northeastern

61 mountains (Pedgley, 1966, 1971, 1974; Jiang et al., 2009; Langodan et al., 2014, Yesubabu et

62 al., 2016).

A trough of low pressure, known as the Red Sea Trough (RST), controls the occurrence of

64 heavy rainfall over the area (Krichak et al., 1997a, b; De Vries et al., 2013). At around 850 hPa,

65 RST is a low-level trough that originates from the equatorial Eastern Africa. It extends

66 northward from the southern Red Sea toward the eastern Mediterranean, influencing regional

67 weather and climatic conditions (Krichak et al., 2012; De Vries et al., 2013). The positions of the

68 RST and two high-pressure systems, one over northeast Africa and another over the Arabian

69 Peninsula, modulate both the location of RSCZ and the intensification of convective activity and 
70 associated rainfall (De Vries et al., 2013). Several studies have attributed the formation of RST

71 to thermal and orographic effects, suggesting that it occurs more frequently in autumn than in

72 winter or spring (Alpert et al., 2004a, b; Tsvieli and Zangvil, 2005, 2007; Krichak et al., 1997a,

73 1997b, 2012).

74 Occasionally, the RST is accompanied by a mid-latitude upper trough, which leads to 75 unstable conditions capable of triggering convective storms and heavy rainfall over the Red Sea 76 and adjoining regions (Kahana et al., 2002; Ziv et al., 2005; Krichak et al., 2012). The dynamics 77 of this type of RST, known as an active RST (ARST), have been well described (Krichak et al., 78 2012; Dayan et al., 2001; Kahana et al., 2002; Ziv et al., 2005; Dayan and Morin, 2006; Tsvieli 79 and Zangvil, 2005, 2007). Recently, De Vries et al. (2013) studied the dynamic features 80 associated with RST and ARST based on an analysis of 13 heavy rainfall events over the Red 81 Sea.

The moisture transport over the Red Sea and the adjacent continents are closely related to 83 the regional and larger-scale circulation patterns, including the North African jets, subtropical 84 westerly jet, inter tropical convergence zone (ITCZ), ENSO, Indian monsoon, and Mediterranean 85 circulation modes linked to the Atlantic circulation patterns, such as the NAO (Bronnimann, 86 2007; De Vries et al., 2013; Kar and Rana, 2014; Kang et al., 2015; Babu et al., 2016). The 87 climatological characteristics of the moisture budget components over the Red Sea suggest that 88 nearly $80 \%$ of the moisture from the Red Sea is transferred over the Arabian Peninsula through 
89 the upper layer transportation (above $850 \mathrm{hPa}$ ), which is closely correlated with the Arabian high 90 (Zolina et al., 2017).

Previous studies of the RSCZ and RST have primarily focused on their formations and 92 associated characteristics, such as moisture transfer and the generation of cyclonic/anticyclonic 93 pressure systems over the Middle East. A few studies also focused on the relationship between 94 the El Niño southern oscillation (ENSO) and rainfall over the Middle East. From the analysis of 95 multi decadal rainfall data over the Arabian Peninsula, Kang et al. (2015) concluded that the wet 96 seasons in the Arabian Peninsula during the recent decades (1980 onwards) show a stronger 97 correlation with ENSO than the early periods (1950-1979). Niranjan Kumar and Ouarda (2014) 98 suggested that the precipitation variability over the United Arab Emirates is mostly influenced by ENSO. Babu et al. (2016) also reported the influence of El Niño and La Niña on the summer and 100 winter precipitation patterns over the Arabian Peninsula. However, the interannual variability of 101 the RSCZ and RST, particularly the role of El Niño and La Niña in modulating the climate of the 102 Middle East and the weather over the Red Sea, has not yet been investigated.

In this study, we analyze the wind field, rainfall, sea surface temperature, convective available potential energy (CAPE), and moisture budget to investigate the potential link of the 105 interannual variability of the RSCZ and RST and the associated rainfall over the Red Sea and 106 adjoining regions to the warm and cold phases of the ENSO during the 37-year period from 1979 107 through 2016 of available ERA-interim data. Our results suggest that El Niño (the warm ENSO 108 phase) is associated with (i) intensification of RSCZ and RST and modification of the rainfall 
109 over the Red Sea and eastern Middle East; (ii) colder than normal air intrusion from the north 110 over the northern half of the Red Sea; (iii) a significant increase of moisture and total column 111 precipitable water vapor; and (iv) an increase in rainfall events over the Middle East. During La

112 Niña, the RSCZ shifts southward, which in turn brings more rainfall over the southern parts of 113 the Red Sea. The remainder of this paper is organized as follows: Section 2 describes the data 114 and methodology; Section 3 presents our analysis and results; and finally Section 4 offers a 115 summary and discussion of our main findings.

116

117

118

119

120

121

122

123

124

125

126 127 were not available).

\section{Data and Methodology}

To investigate the dynamics of the RSCZ and RST, we examined several variables from the ERA-Interim reanalysis for the 37-year period 1979-2016 (Dee et al., 2011, T255 and 60 model levels) provided by the European Centre for Medium-Range Weather Forecasts (ECMWF). We analyzed monthly mean values of surface and $850 \mathrm{hPa}$ winds, $850 \mathrm{hPa}$ geopotential, CAPE, total column precipitable water (TCPW), and vertically integrated moisture convergence. We also used the Advanced Very High Resolution Radiometer (AVHRR) infrared satellite sea surface temperature (SST) data (Reynolds et al., 2007) available at $0.25^{\circ} \times 0.25^{\circ}$, daily APHRODITE precipitation data sets (version V1101, Yatagai et al., 2012) between 1979 and 1997 and Tropical Rainfall Measuring Mission (TRMM) 3B42 version 7 data (Huffman et al., 2007, Huffman and Bolvin, 2012) between 1998 and 2016 (TRMM data for 1979 to 1997 
Both the APHRODITE and TRMM data sets are available at $0.25^{\circ} \times 0.25^{\circ}$ resolution.

129 The TRMM estimated precipitation overestimates station rainfall over the Arabian Peninsula by 130 approximately 10\% on average (Almazroui, 2011 and Almazroui et al., 2012). The mean 131 observed and TRMM data (in brackets) in millimeters are 25.81 (25.27), 29.76 (35.74), 9.21 132 (12.85), and 14.10 (14.33) during winter, spring, summer and autumn respectively. The 133 correlation coefficient between the TRMM and the rain-gauge rainfall data is about 0.90 , with a $13499 \%$ level of significance on the monthly scale. TRMM has been described as the best 135 precipitation dataset for the Middle East (Almazroui, 2011; Almazroui et al., 2012). 136 APHRODITE's (Asian Precipitation - Highly-Resolved Observational Data Integration Towards 137 Evaluation) daily gridded precipitation is the only long-term (1951 onward) continental scale 138 daily product that uses a dense network of daily rain-gauge data for Asia. Tabarhte et al. (2012) 139 inter-compared different gridded global (CRU, CPC, DEL, GPCC, ERA40) and regional 140 (APHRODITE and E-OBS) precipitation datasets over the Mediterranean and the Middle East 141 for the period 1961-2000. The study concluded that APHRODITE is a unique source of 142 precipitation data for the Middle East region with minimal errors and highest correlations among 143 the different examined datasets. The quality of the latest version of APHRODITE (version 144 V1101) was further improved due to the additional rainfall observations that were included in the 145 APHRODITE data from the southward extension of the APHRODITE domain. In addition, we used precipitation data from more than 110 rain gauges placed across the 147 region. The precipitation data are available for the entire period of study (Kenawy and McCabe, 148 2016; Almazroui, 2011). The El Niño (1994/1995, 2002/2003, 2004/2005, 2006/2007, 
149 2009/2010, 2015/2016) and La Niña (1983/1984, 1988/1989, 1998/1999, 2000/2001, 2007/2008, 150 201/2012) years were selected based on the central Pacific ENSO Index (Zhiyu et al., 2015).

\section{3. Results}

We investigate the influence of El Niño and La Niña on the RSCZ, RST, and their 153 associated rainfall by analyzing winds, geopotential, temperature, SST, CAPE, TCPW, 154 evaporation and moisture convergence. The rainfall is retrieved from APHRODITE and TRMM, 155 from October to January, a period representative of the most pronounced RSCZ and RST 156 (Krichak et al., 2012; De Vries et al., 2013).

\subsection{The wind regime}

The 37-year ECMWF climatology of $10 \mathrm{~m}$ winds from October to January (Fig. 1a) shows a well-organized convergence zone (RSCZ) at about $18^{\circ} \mathrm{N}$ across the Red Sea formed by the convergence of southeastern and northwestern winds. This is a salient winter feature throughout 161 the investigated period, with some variability in its position and intensity. Composite means 162 computed exclusively for El Niño and La Niña years are shown in Figures $1 \mathrm{~b}$ and 1c, 163 respectively. El Niño years are characterized by about $15-20 \%$ lower wind speeds in the northern 164 Red Sea and 10-20\% higher wind speeds in the southern Red Sea and Gulf of Aden compared 165 with the climatological mean (Figs. $1 \mathrm{~b}$ and 1d), resulting in a broader $\operatorname{RSCZ}\left(17^{\circ}-21^{\circ} \mathrm{N}\right)$. 166 Alternatively, La Niña years are characterized by $\sim 15 \%$ stronger northwest winds in the northern

167 Red Sea and slightly weaker southeasterly winds in the southern Red Sea (5-10\%) compared 168 with the climatological mean (Fig. 1c), causing a southward shift of the convergence zone. 
169 Figure 1d confirms the differences in wind flow between the composite means of El Niño and La 170 Niña years, suggesting a significant increase (about 20-30\%) in the narrow flow branch of 171 southeasterly winds in the southeastern part of the Red Sea $\left(12^{\circ} \mathrm{N}\right.$ to $\left.20^{\circ} \mathrm{N}\right)$ and East Arabian

172 Peninsula. This observation is consistent with the findings of Raitsos et al. (2015), who 173 attributed the increased chlorophyll concentration in the Red Sea to stronger southeasterlies 174 during El Niño winters. Ha et al., (2012) also showed that the interannual variability in the East 175 Asian winter monsoon is highly related to ENSO and Arctic Oscillation. During El Niño, the 176 Siberian High (SH) strengthens significantly and shifts southward. As a result, stronger 177 southerlies over the southern Red Sea during El Niño years may increase evaporation and feed 178 more moisture to RSCZ.

179 Along with the differences in wind speeds, we also observed changes in wind direction 180 between El Niño and La Niña years over the Middle East. In particular, the northwesterly winds 181 over the northwestern domain of the study area during El Niño years shifted to northerlies during 182 La Niña years.

$183 \quad 3.2$ Winds, geopotential and temperature at $850 \mathrm{hPa}$

To understand the influence of El Niño and La Niña on RSCZ and RST and their 185 associated dynamics, we analyzed the winds and the geopotential fields at $850 \mathrm{hPa}$. The 186 composite means of El Niño and La Niña years are presented in Figure 2. The mean circulation 187 at $850 \mathrm{hPa}$ (Fig. 2a) clearly exhibits two high-pressure domains around $25^{\circ} \mathrm{N}$ on the eastern and 188 western sides of the Red Sea; the western high-pressure system over the Sahara is stronger than 
189 the eastern system over the Arabian Peninsula. Between these two high-pressure systems is a 190 squeezed low-pressure trough, named RST (Krichak et al., 1997a, b; De Vries et al., 2013). At $191 \sim 30^{\circ} \mathrm{N}$, a weaker trough, known as the subtropical jet, is apparent between the two high-pressure 192 systems. De Vries et al. (2013) studied the relationship between the moisture transport over the 193 region and the pressure systems and concluded that the intensities and positions of the high194 pressure systems strongly influence RST, which ultimately modulates moisture transport and 195 associated rainfall patterns over the Middle East. The positions and intensities of these semi196 permanent systems influence the north-to-south movement of RSCZ. The difference (E1 Niño 197 mean, Fig. 2b) shows a distinct northward movement of the Saharan high-pressure system, with 198 a decrease in intensity ranging from 5 to $10 \mathrm{gpm}$. As shown in Figure 2, at $850 \mathrm{hPa}$, a cold air 199 mass originating from the Mediterranean region enters from the lower troposphere towards 200 RSCZ. Similarly, we also considered mean temperatures at different levels (Fig. 3). At lower 201 levels (Fig. 3b and 3c), colder temperatures over the northwestern parts of the Red Sea are 202 observed during El Niño than during normal and La Niña years. In addition, during El Niño 203 years air temperatures are warmer on both sides of the Red Sea, and the temperature difference is 204 more pronounced when compared to air temperatures during La Niña years (Fig. 3c). The 205 stronger winds in the region of the RST (south of the Red Sea) transfer moisture from the south 206 towards the RSCZ. When these moist and warm air masses meet the cold masses transferred by 207 the trough over the northern Red Sea, a thermal gradient occurs and leads to stronger than 208 normal convection. Furthermore, the cyclonic circulation associated with RSCZ and the 209 channeling by the Ethiopian Mountains steers orographic lifting, which results in increased air 
210 uplift that favors stronger convection and higher rainfall (Krichak et al., 2012; De Vries et al., 211 2013). During La Niña years (Fig. 2c), the trough over the northern Red Sea is weaker and is 212 associated with dry northwest winds that extend along the Red Sea. Figure 2d (El Niño - La 213 Niña) shows a pronounced signal during La Niña years compared to the El Niño years (Fig. 2b);

214 northwestward movement of the Saharan high-pressure system that has decreased in intensity 215 with eastward movement of the Arabian high-pressure system that has increased in intensity. The 216 position of these high-pressure systems directs the warm air from south of RSCZ to meet the 217 relatively cold extra-tropical air masses from north of RSCZ, plausibly resulting in higher 218 rainfall during El Niño periods (see Section 3.3). Although moisture seems to be preferably 219 transported toward the western Red Sea, the intensities of the two anticyclones over the 220 northwest and eastern sectors are crucial to the movement of moisture towards Saudi Arabia. The 221 two high-pressure systems are stronger during El Niño than La Niña years, and favor increased 222 rainfall over the eastern Red Sea during El Niño periods (i.e., the northern side of RSCZ, mostly 223 over northern Saudi Arabia). We have also analyzed the winds and geopotential at $850 \mathrm{hPa}$ level 224 from the long-term 21st century reanalysis datasets from ECMWF covering (32) El Nino and 225 (28) La Nina events (not shown). The results clearly show that the composite anomalies of El 226 Niño and La Nina and the difference between El Niño and La Nina also exhibit the same patterns 227 as those presented in Figure 2 (b, c and d). Since, observed daily rainfall and Sea Surface 228 Temperature data were not available for this long-term period, we limit our further analysis to a 229 period when the observations are available. 
The mean amount of rainfall and the number of rainy days are relatively low across the

232

233

234

235

236

237

238

239

240

241

242

243 study area (Benestad et al., 2012). Nonetheless, we analyzed the interannual variability of rainfall over the Red Sea in relation to El Niño and La Niña years. The rainfall climatology estimated from APHRODITE and TRMM between October and January and the difference between El Niño and La Niña years are presented in Figure 4. The mean rainfall is higher below $15^{\circ} \mathrm{N}$ and north of the Red Sea (Fig. 4a). The RSCZ generates a rainfall zone over the Red Sea between $16^{\circ} \mathrm{N}$ and $21^{\circ} \mathrm{N}$, and as such the amount of rainfall and its spatial variability are highly dependent on the movement and intensity of the RSCZ. A comparison of the mean rainfall during El Niño and La Niña years (Fig. 4b), especially along RSCZ and over the north and northeast regions of Saudi Arabia, shows that the amount of rainfall is higher during El Niño than La Niña years. The stronger RSCZ with its northward movement during El Niño years favors stronger convection and higher-than-normal amounts of rainfall over the northern parts of Saudi Arabian region, and decreases the amount of rainfall over the south-central Red Sea.

Figure 5 presents a Hovmöller diagram (time-longitude) of the mean rainfall averaged between $18^{\circ}-24^{\circ} \mathrm{N}$ over the Red Sea for all (Fig. 5a), normal (Fig. 5b), El Niño (Fig. 5c), and La Niña (Fig. 5d) years during winter (October-January). Isolated rainfall events occur in all four cases, mainly at longitudes between $37^{\circ}$ and $50^{\circ} \mathrm{E}$. El Niño winters experience the highest mean rainfall from October to January with more isolated rainfall events over a wider region (Fig. 5c), whereas the highest rainfall during La Niña is confined to October and November. The results also suggest that during El Niño years, rainfall moves towards the north of RSCZ whereas during La Niña it is confined to the south of RSCZ. Rainfall is never continuous over several days and 
252 there is no indication of any atmospheric wave propagation. During La Niña years, there is a 253 distinct reduction in both the amount of rainfall and the number of rainy days (Fig. 5d). Figure 6 254 presents a time-latitude diagram of the mean total rainfall averaged over $37.5^{\circ}-41^{\circ} \mathrm{E}$ for normal 255 (Fig. 6a), El Niño (Fig. 6b) and La Niña (Fig. 6c) winters. Whereas rainfall is concentrated over 256 the southern parts of the Red Sea and adjoining regions during normal and La Niña years, a 257 northward shift of rainfall over time is evident during El Niño years. These findings suggest that 258 the northward shift of RSCZ increases the amount of rainfall over the northern parts of the Red 259 Sea during El Nino, whereas a southward shift of RSCZ increases the amount of rainfall in the 260 southern parts of the Red Sea.

To substantiate these results, we analyzed daily rainfall data from the east and west coasts

262 of the Red Sea along the RSCZ. Between October and January, fewer rainy days are observed on 263 average in the area between $18^{\circ}-24^{\circ} \mathrm{N}$ and $34^{\circ}-36^{\circ} \mathrm{E}$ (western side of the Red Sea, Fig. 7a) than 264 in the area between $18^{\circ}-24^{\circ} \mathrm{N}$ and $40^{\circ}-42^{\circ} \mathrm{E}$ (eastern side, Fig. $7 \mathrm{~b}$ ). Heavy rainfall events are 265 rare over both sides in October. The number of rainfall events is considerably higher (Fig. 7c) 266 during El Niño years. In general, the relatively high amount of rainfall in October on both the 267 western and eastern sides of the Red Sea is associated with a more active, stronger RSCZ. 268 Similarly, the eastern coast of the Red Sea $\left(18^{\circ}-24^{\circ} \mathrm{N}\right.$ and $\left.40^{\circ}-42^{\circ} \mathrm{E}\right)$ experiences more rainfall 269 than the western coast and also more rainy days (Fig. 7d) with higher rainfall during October, 270 December, and January. With the exception of a few days in January, more rainfall and rainy 271 days occurred during El Niño years compared with the long-term mean, normal years, and La 272 Niña periods. At the same time, the amount of rainfall is higher in the east, north, and 
273 northeastern parts of the Red Sea during El Niño years. The intrusion of cool air into the Middle 274 East (Section 3.2) that is likely associated with strong and prolonged winters over the 275 Mediterranean Sea during El Niño years (Moron and Plaut, 2003; Mariotti et al., 2002; Lopez et 276 al., 2012, 2015; Wang et al., 2014) plays a significant role. This intrusion results in a higher 277 amount of rainfall over the Middle East and more rainy days over the Red Sea and adjoining 278 regions during El Niño winters. Kang et al. (2015) reported that during recent years, the 279 intensified upper-level zonal wind enhances the frequent passages of transients over this region 280 and enhances the rainfall amount.

282 over the region (Kenawy and McCabe, 2016; Almazroui, 2011) helps in understanding the 283 variability of rainfall during El Niño and La Niña years. Based on the total amount of rainfall at 284 each station, we categorized stations into two groups. The first group includes stations with 285 higher amounts of rainfall recorded during El Niño years and the second group includes stations 286 with higher amounts of rainfall during La Niña years. Figure $8 \mathrm{a}$ and $8 \mathrm{~b}$ respectively present 287 histograms of the mean seasonal accumulated rainfall during El Niño and La Niña years. Figure 288 8c shows the distribution of the rain gauges over the study area. The stations in the group with a 289 higher amount of rainfall during El Niño years are marked in red; those with a higher amount of 290 rainfall during La Niña years are marked in blue. In general, the gauges located in the northern 291 parts of RSCZ recorded more rainfall during El Niño years (red), whereas the gauges located in 292 the southern parts of RSCZ and in the western parts of Saudi Arabia recorded more rainfall 293 during La Niña years (blue). The distribution of rainfall accumulation at different stations 
294 suggests that El Niño brings a higher amount of rainfall windward of the southern mountains 295 near the Red Sea coastline. In contrast, a higher amount of rainfall is observed on the lee side of 296 the mountains during La Niña years. The higher amount of rainfall windward of the mountains 297 during El Niño years could be attributed to orographic-driven convection along with moisture 298 from the Arabian Sea entering through Yemen and adjoining regions (Krichak et al., 2012; De 299 Vries et al., 2013).

\subsection{Convective available potential energy and sea surface temperature}

In arid and semi-arid regions, rainfall events can be characterized as discontinuous,

302 highly variable rainfall pulses with unpredictable frequency and intensity (Pedgley, 1971, 1974;

303 Kenawy and McCabe, 2016). Most rainfall events are associated with storms triggered by strong 304 convection. CAPE is an indicator of the instability of the atmospheric column; an increase of 305 CAPE indicates higher probability of convective storms. Figure 9a shows CAPE from October to 306 January as computed from ERA Interim data, and Figure 9b plots the difference in CAPE 307 between El Niño and La Niña years. The mean CAPE values during El Niño years are higher 308 than during La Niña and normal years, an indication that the El Niño years favor convective 309 storm conditions (Cotton et al., 2011).

An oceanic parameter that can affect the instability of the atmospheric column is the sea 311 surface temperature (SST). Warmer than normal water may trigger convective storms over the 312 sea (Deb et al., 2008). The anomalies in SST for El Niño and La Niña years during the 35-year 313 period from 1979 through 2014 are plotted in Figures 10a and 10b. These figures clearly show 
314 that during El Niño years, warmer surface temperatures occur during October, November and 315 December in the southern parts of the Red Sea. Similar features are also observed in the surface 316 air temperatures (Figure 3a) along the Red Sea. The observed SST indicates a northward 317 propagation of warmer water from October to January during El Niño years. This may be related 318 with the strong southeasterly winds in the Gulf of Aden, which push the warm water from the 319 Arabian Sea into the Red Sea during El Niño years. In contrast, during La Niña years, slightly 320 negative SST anomalies seem to propagate from south to north along the southern Red Sea 321 between November and January. These colder surface waters are less favorable to the 322 development of convection events over the Red Sea.

\section{$323 \quad 3.5$ Moisture balance}

In general, over the tropics, the intensity of rainfall is associated with the convergence or

325 divergence of water vapor flux (Rao et al., 2002, Li et al., 2013, Wei et al., 2015, Ramakrishna 326 et al., 2016; Zolina et al., 2017). Therefore, examining the amount of moisture over a broader 327 area around the Red Sea and its probable origin is also of interest. We aim to clarify whether the 328 increase in rain during El Niño years is associated with higher moisture over the studied area or 329 if is it simply a result of stronger than normal convection in RSCZ. To measure atmospheric 330 moisture, we use TCPW and moisture convergence that is vertically integrated from the surface 331 to $300 \mathrm{hPa}$.

332 The moisture budget equation can be written as: 


$$
\frac{\partial w}{\partial t}=-\nabla Q+E-P \quad \text { with } Q=\frac{1}{g} \int_{p_{0}}^{p_{t}} q \mathbb{v d p}
$$

333

334 where $p_{t}=300 \mathrm{hPa}, p_{0}$ is the surface pressure, $g$ is the accelaration of gravity, and $\mathbb{V}$ is 335 horizontal wind vector. Equation (1) states that the rate of change in total precipitable water $(w)$ in the column is equal to the difference between evaporation (E) and the sum of precipitation and the vertically integrated moisture convergence $(\nabla Q)$.

Figure 11 plots the total precipitable water for the mean (Fig. 11a), El Niño (Fig. 11b), La Niña (Fig. 11c), and the difference between El Niño and La Niña (Fig. 11d) years. The latter shows positive values over the northern Red Sea and negative values over the southern Red Sea. However, the differences are on the order of $5 \mathrm{~g} / \mathrm{kg}$, which are non-significant. Figure 12 shows the mean vertically integrated moisture convergence $\left(\mathrm{kg} \cdot \mathrm{m}^{-2} \cdot \mathrm{s}^{-1}\right)$ for all (Fig. 12a), El Niño (Fig. 12b), La Niña (Fig. 12c) and the difference between El Niño and La Niña (Fig. 12d) years. During El Niño years (Fig. 12b), a greater amount of moisture (about 10-25\%) is available along the Red Sea and in Saudi Arabia than during mean and La Niña years. Figure 12d clearly outlines an increased south-to-north transport of moisture $\left(\mathrm{kg} \cdot \mathrm{m}^{-1} \cdot \mathrm{s}^{-1}\right)$ over the Red Sea during El Niño years; this moisture turns toward northwestern Saudi Arabia after crossing RSCZ, suggesting that rain is more likely to occur in the north of RSCZ than in the south of RSCZ during El Niño years. The correlation of monthly mean $(\sim 36 \times 4$ data points at every grid) of TCPW and moisture convergence with their corresponding multivariate ENSO index (MEI, http://www.esrl.noaa.gov/psd/enso/mei/table.html) are computed and presented in Figure 13. The 
352 correlations are highly significant (>95\%) over RSCZ and eastern Saudi Arabia. A negative 353 correlation between moisture convergence and MEI indicates higher moisture convergence (Fig.

354 13b) in the central Saudi Arabia and coastal regions of the northern Red Sea. Another interesting 355 characteristic is the evaporation variability during El Niño and La Niña years (Fig. 14). The 356 mean values of evaporation for all (Fig. 14a) and the anomalies of El Niño (Fig. 14b) and La 357 Niña (Fig. 14c) years indicate that during El Niño periods, evaporation is lower over the northern 358 parts and higher over the southern parts of the Red Sea. In contrast, during La Niña years, 359 evaporation is higher over the northern parts of the Red Sea.

The difference in evaporation between El Niño and La Niña (Fig. 14d) years suggests that evaporation is $10-15 \%$ lower in El Niño years, with positive values over the Red Sea and 362 Saudi Arabia. The lower evaporation over the northern Red Sea is related to the lower SST (Fig. 363 10a) and weaker northwesterly winds. The mean vertically integrated TCPW and moisture 364 values suggest that the Red Sea receives the majority of its moisture from the Indian Ocean 365 during the winter monsoon, and both values are highest over RSCZ during El Niño years. This 366 confirms that stronger RSCZ conditions are the dominant factor associated with the increased 367 rainfall during El Niño winters. The rate of change in precipitable water vapor difference $\left(\frac{\partial w}{\partial t}\right)$ is 368 small between El Niño and La Niña years $(5 \mathrm{~g} / \mathrm{kg})$ compared with the mean values of $60 \mathrm{~g} / \mathrm{kg}$. 369 Generally, stronger moisture convergence is related to higher amounts of rainfall. Although 370 stronger moisture convergence occurred during El Niño years, the excess rainfall was only 0.5 $371 \mathrm{~mm} /$ day compared to La Niña periods. This observation is explained by Equation (1), where we 372 expect equilibrium between $\mathrm{E}, \mathrm{P}$ and $-\nabla Q$. 
374 for winter seasons and presented in supplementary Figure S1. The climatological mean 375 evaporation shows nearly 50-75\% higher magnitude over the northern Red Sea (around 24N) 376 than the southern Red Sea. The analysis also confirms that the Red Sea and adjacent oceans are 377 the major sources of moisture over the region. It is important to note that evaporation is high/low 378 over the southern/northern Red Sea during El Niño and it is exactly opposite during La Niña. 379 The mean climatological winter precipitation is higher over the north and northeastern parts of 380 the Saudi Arabia during El Niño and is minimum during La Niña. The mean net evaporation (E381 P) patterns of climatology, El Niño, and La Niña over the Red Sea exhibit similar from 382 evaporation (E) (minimal precipitation). The mean vertically integrated moisture convergence 383 (Fig S1d) suggests that the moisture from the Arabian Sea is transported to the northeastern parts 384 of the Saudi Arabian peninsula through the Red Sea. During El Niño, the vertically integrated 385 moisture convergence is about $15-20 \%$ higher than normal and La Niña over the northern parts 386 of the Red Sea, indicating higher probability of precipitation. The eastward advection of the 387 vertically integrated moisture is mainly controlled by the position of RST and high pressure 388 systems on both sides of Red Sea. Since the difference in precipitation is very small, we 389 anticipate that the total evaporation difference $(1 \mathrm{~mm} /$ day $)$ is counter balanced by the divergence 390 of the water vapor. A similar water balance argument for arid regions is demonstrated in 391 previous studies, e.g., Star and Peixoto (1958).

A schematic description of the synoptic scale features and related dynamical processes over RSCZ during normal, El Niño and La Niña years is illustrated in Figure 15. While El Niño 
394 favors the northeastern Red Sea and adjoin region with an increased number of rainy days, La 395 Niña brings more rainfall to the southern parts of the Red Sea. During El Niño periods (Fig.15b), 396 the significant warming over the tropical regions in summer produces increased temperature 397 gradients from pole to equator and amplifies (Bronnimann, 2007) the polar jet, which in turn 398 triggers a shift of the subtropical westerly jet (STJ) towards the equator in the following winter. 399 These changes accompanied with a northward moisture transport from the Arabian Sea to the 400 Red Sea set favorable conditions for rainfall over the northeastern parts of the Red Sea. During 401 La Niña (Fig. 15c), stronger northeast surface winds blowing from north pushes the RSCZ and 402 RST southward, the presence of the Arabian Anti cyclone over the southern Arabian Peninsula 403 transports the moisture through the Gulf of Aden towards the southern Saudi Arabia and favors 404 rainfall in the region.

405 4. Summary

406 The distribution of rainfall over the Red Sea and adjacent regions depends on the strength and 407 location of RSCZ and RST. In this study, we analyzed the interannual variability of RSCZ and 408 associated rainfall. We investigated the differences in the wind flow patterns around RSCZ 409 during El Niño, La Niña and normal years. Weaker northwest winds over the northern Red Sea 410 and stronger southeast winds over the southern Red Sea during El Niño years are observed 411 compared with stronger northwest winds over the northern Red Sea and weaker southeast winds 412 over the southern Red Sea during La Niña years. These varying wind conditions shift the 413 position of RSCZ toward the north during El Niño years and toward the south during La Nina 
414 years. During El Niño years, the stronger southeast winds over the Gulf of Aden pump warmer 415 water from the Arabian Sea into the Red Sea, causing increased SST, evaporation, and transport 416 of more moisture toward RSCZ. Stronger convection and higher moisture in the air increase the 417 number of rainy days and the total amount of rainfall over the Red Sea and the Middle East 418 during El Niño years. The prolonged and relatively cold winters over the Mediterranean Sea is 419 associated with El Niño propels cold air at $850 \mathrm{hPa}$ towards RSCZ. This intrusion of cold air is 420 integral to the formation of a stronger than normal RST. At surface, RSCZ and RST trigger 421 convection over the region, subsequently increasing rainfall over the Red Sea and adjoining 422 areas. The position of $\mathrm{RST}$ at $850 \mathrm{hPa}$ and the subtropical jet associated with stronger 423 anticyclonic systems along the eastern and western Red Sea are prominent features that transport 424 moisture between the Arabian and Mediterranean Seas and across the Red Sea and its adjoining 425 regions. Occasionally, anticyclonic systems on the eastern and western Red Sea intensify the 426 low-pressure system that forms over the northern Red Sea, a pattern that can contribute 427 considerably to the transport of moisture towards the Saudi Arabian peninsula, particularly to its 428 northern regions. The correlations of MEI with TCPW and moisture convergence during winter 429 suggest that the majority of moisture into the Red Sea is transported from the Indian Ocean and 430 that an increase in TCPW is favored during El Niño years.

Our analysis shows that the strengthening of the conditions of RSCZ, the deepening of $432 \mathrm{RST}$, and increases in SST and CAPE are the dominant factors regulating the associated stronger 433 convection and stronger rainfall over the Red Sea and adjoining regions during El Niño years. 
434 During El Niño, the upper tropospheric cyclonic circulation shifts the position of STJ to the 435 Central Arabian Peninsula (Kang et al., 2015), which directly enhances the moisture 436 convergence over the region and subsequently increases the precipitation from the frequent 437 passage of transients. The northward migration of RST and RSCZ, southward shift of STJ and 438 increased strength of circulation patterns enhance the moisture advection towards the 439 northeastern parts of Saudi Arabia.

This study focused on the ENSO influence on the interannual variability of winter rainfall 441 over the Red Sea region and its relation to the movement of the RSCZ. The dynamical links 442 between the reported local processed and the large scale modes are still yet to be investigated and 443 this will be address in future study.

\section{Acknowledgments:}

445 This research was funded by King Abdullah University of Science and Technology (KAUST) 446 and the Saudi ARAMCO Marine Environmental Research Center at KAUST (SAMERCK). This 447 research made use of the resources of the Supercomputing Laboratory and/or computer clusters 448 at KAUST.

\section{References:}

450 Abualnaja, Y, Papadopoulos, VP, Josey, SA, Hoteit I, Kontoyiannis H, Raitsos, DE. 2015. 451 Impacts of Climate Modes on Air-Sea Heat Exchange in the Red Sea. J. Climate, 28, 2665452 2681, doi: 10.1175/JCLI-D-14-00379.1. 
453 Almazroui M, Islam MN, Jones PD, Athar H, Rahman MA. 2012. Recent climate change in the 454 Arabian Peninsula: Seasonal rainfall and temperature climatology of Saudi Arabia for 1979455 2009. Atmos. Res., 111,29-45, doi:10.1016/j.atmosres.2012.02.013.

456 Almazroui M. 2011. Calibration of TRMM rainfall climatology over Saudi Arabia during 1998457 2009. Atmos Res., 99, 400-414, doi:10.1016/j.atmosres.2010.11.006

458 Alpert P, Osetinsky I, Ziv B, Shafir H. 2004a. Semi-objective classification for daily synoptic systems: Application to the Eastern Mediterranean climate change. Int. J. Climatol., 24 (8), 1001-1011, doi:10.1002/joc.1036

461

462

463

464

465

466

467 468 469 470

Alpert P, Osetinsky I, Ziv B, Shafir H. 2004b. A new seasons definition based on classified daily synoptic systems: An example for the Eastern Mediterranean. Int. J. Climatol., 24(8), 10131021, doi:10.1002/joc.1037.

Babu CA, Jayakrishnan PR, Varikoden H. 2016. Characteristics of precipitation pattern in the Arabian Peninsula and its variability associated with ENSO. Arab J Geosci, 9: 186. doi:10.1007/s12517-015-2265-X

Benestad R, Nychka D, Mearns L. 2012. Spatially and temporally consistent prediction of heavy precipitation from mean values. Nat. Clim. Change, 2, doi:10.1038/NCLIMATE1497.

Bro“nnimann S, 2007. Impact of El Niño- Southern Oscillation on European climate, Rev. Geophys., 45, RG3003, doi:10.1029/2006RG000199. 
471 Cotton WR, Bryan GR, Van den Heever SC, 2011. Storm and cloud dynamics the dynamics of 472 clouds and precipitating mesoscale systems. International Geophysics series. 99, 1-809. $473 \quad$ Academic press, ISBN: 978-0-12-088542-8.

474 Dayan U, Morin E, 2006. Flash flood-producing rainstorms over the Dead Sea. New frontiers in 475 Dead Sea Paleo environmental research: Geological Society of America Special Paper 401, 476 53-62, doi:10.1130/2006.2401(04).

477 478

479

480

481

482

483

484

485

486

487

488

489

490

Dayan U, Ziv B, Margalit A, Morin E, Sharon D. 2001. A severe autumn storm over the MiddleEast: Synoptic and mesoscale convection analysis. Theor. Appl. Climatol, 69(1-2), 103-122, doi:10.1007/s007040170038.

De Vries AJ, Tyrlis E, Edry D, Krichak SO, Steil B, Lelieveld J. 2013. Extreme precipitation events in the Middle East: Dynamics of the Active Red Sea Trough. J. Geophys. Res. Atmos., 118, 7087-7108, doi:10.1002/jgrd.50569.

Deb SK, Kishtawal CM, Pal PK, Joshi PC. 2008. Impact of TMI SST on the simulation of a heavy rainfall episode over Mumbai on 26 July 2005, Monthly Weather Review, 136 (10), $3714-3741$

Dee DP, Uppala SM, Simmons AJ, Berrisford P, Poli P, Kobayashi S, Andrae U, BalmasedaMA, Balsamo G, Bauer P, Bechtold P, Beljaars ACM, van de Berg L, Bidlot J, Bormann N, Delsol C, Dragani R, Fuentes M, Geer AJ, Haimberger L, Healy SB, Hersbach H, Hólm EV, Isaksen L, Kållberg P, Köhler M, Matricardi M, McNally AP, Monge-Sanz BM, Morcrette J-J, Park B-K, Peubey C, de Rosnay P,Tavolato C, Thépaut J-N, Vitart F. 2011. The ERA- 
Interim reanalysis:configuration and performance of the data assimilation system. Q. J. R. Meteorol. Soc. 137(656): 553-597, doi: 10.1002/qj.828.

493 Ha KJ, Heo KY, Lee SS, Yuna KS, Jhunc JG. 2012. Variability in the East Asian 494 Monsoon: a review. Meteorol. Appl. 19: 200-215.

495

496

497

498

499

500

501

502

503

504

505

506

507

508

Huffman GJ, Adler RF, Bolvin DT, Gu G, Nelkin EJ, Bowman KP, Hong Y, Stocker EF, Wolff DB. 2007. The TRMM multi-satellite precipitation analysis: Quasi-global, multi-year, combined-sensor precipitation estimates at fine scale. J. Hydro meteorol., 8, 38-55, doi: http://dx.doi.org/10.1175/JHM560.1.

Huffman GJ, Bolvin DT. 2012. TRMM and other data precipitation data set documentation (ftp://meso-a.gsfc.nasa.gov/pub/trmmdocs/3B42_3B43_doc.pdf).

Jiang H, Farrar JT, Beardsley RC, Chen R, Chen C. 2009. Zonal surface wind jets across the Red Sea due to mountain gap forcing along both sides of the Red Sea. Geoph. Res. Letters, 36, L19605. doi:10.1029/2009GL040008.

Kahana R, Ziv B, Enzel Y, Dayan U. 2002. Synoptic climatology of major floods in the Negev desert. Israel, Int. J. Climatol, 22 (7), 867-882, doi:10.1002/joc.766.

Kang, In-Sik, Irfan Ur Rashid, Fred Kucharski, Mansour Almazroui, Abdulrahman A. Al Khalaf, 2015. Multi-decadal changes in the relationship between ENSO and wet-season precipitation in the Arabian Peninsula. Journal of Climate, 28, 12, 4743-4752. 
509 Kenawy AM, McCabe MF. 2016. A multi-decadal assessment of the performance of gauge- and model-based rainfall products over Saudi Arabia: climatology, anomalies and trends. Int. J. Climatol., 36: 656-674, doi: 10.1002/joc.4374

512 Krichak SO, Alpert P, Krishnamurti TN. 1997a. Interaction of topography and tropospheric flow - A possible generator for the Red Sea Trough? Meteorol. Atmos. Phys., 63(3-4), 149-158, doi:10.1007/

515

516

517

Krichak SO, Alpert P, Krishnamurti TN. 1997b. Red Sea Trough/cyclone development numerical investigation. Meteorol. Atmos. Phys., 63 (3-4), 159-169, doi:10.1007/BF01027382.

Krichak SO, Alpert P. 1998. Role of large scale moist dynamics in November 1-5, 1994, hazardous Mediterranean weather. J. Geophys. Res., 103, 453-468, doi:10.1029/98JD01710.

Krichak SO, Breitgand JS, Feldstein SB. 2012. A conceptual model for the identification of the Active Red Sea Trough Synoptic events over the southeastern Mediterranean. J. App. Meteorol. Climatol, 51(5), 962-971, doi:10.1175/JAMC-D-11-0223.1.

Langodan S, Cavaleri L, Yesubabu V, Hoteit I. 2014. The Red Sea: A Natural Laboratory for Wind and Wave Modeling. J. Phys. Oceanography, 44, 3139-3159.

Langodan, S., L Cavaleri,, Yesubabu, V., Hoteit, I., 2015. Wind $\square$ wave source functions in opposing seas. J. Geophys. Res: Oceans 120 (10), 6751-6768

Li L, Li W, Barros AP. 2013. Atmospheric moisture budget and its regulation of the summer precipitation variability over the Southeastern United States. Clim. Dyn., 41:613-631 
529 López-Parages J, Rodríguez-Fonseca B, Laurent Terry. 2015. Mechanism for the multi decadal 530 modulation of ENSO teleconnection with Europe. Clim. Dyn., 45, 867-880.

531 López-Parages J, Rodríguez-Fonseca B. 2012. Multi decadal modulation of El Niño influence on 532 the Euro-Mediterranean rainfall. Geophys. Res. Lett, 39, L02704, doi:10.1029/2011GL050049.

Mariotti A, Zeng N, Lau KM. 2002. Euro-Mediterranean rainfall and ENSO-a seasonally varying relationship. Geophys. Res. Lett., 29(12), doi:10.1029/2001GL014248

536 Moron V, Plaut G. 2003. The impact of El Niño-southern oscillation upon weather regimes over 537 Europe and the North Atlantic during boreal winter. Int. J. Climatol, 23, 363-379.

538 Niranjan Kumar K, Ouarda TBMJ. 2014. Precipitation variability over UAE and global SST 539 teleconnections. J. Geophys. Res. Atmos., 119, doi:10.1002/2014JD021724. 8696.1966.tb02776.

542 Pedgley DE. 1971. A Heavy Rainstorm over North-Western Arabia. Proc. Syrup. Trop. Met, 543 Honolulu, 1970, E VII 1-6.

544 Pedgley DE. 1972. Desert depressions over North-east Africa, Meteorological Magazine, $545 \quad$ London, 101, 228-244.

546 Pedgley DE. 1974. The winter and spring weather at Riyadh, Saudi Arabia. Meteorological 547 Magazine, London, 103, 551.589.1 (53), 225-236. 
548 Raitsos DE, Yi X, Platt T, Racault MF, Brewin RJW, Pradhan Y, Papadopoulos VP, 549 Sathyendranath S, Hoteit I. 2015. Monsoon oscillations regulate fertility of the Red Sea, $550 \quad$ Geophys. Res. Lett., 42, doi:10.1002/2014GL062882.

551 Ramkrishna SSVS, Rao VB, Srinivas BR, Hari Prasad D, Nanaji Rao N, Roshmitha P. 2016. A 552 study of 2014 record drought in India with CFSv2 model: role of water vapor transport. 553 Clim. Dyn., DOI 10.1007/s00382-016-3343-9

554 Rao VB, Srinivasarao C, Fernandez JPR, Franchito SH. 2001. A Diagnosis of rainfall over South 555 America during the 1997/98 El Niño event. Part II: Role of water vapor transport and 556 stationary waves. Journal of Climate, $15,512-521$.

557 Reynolds WR, Smith TM, Liu C, Chelton DB, Casey KS, Schlax MG. 2007. Daily High558 559 560 561 Resolution-Blended Analyses for Sea Surface Temperature. J. Climate 20, 5473-5496, doi: 10.1175/2007JCLI1824.1

Star VP, Peixoto JP. 1956. On the Global Balance of Water Vapor and the Hydrology of Deserts. Tellus, 10, 188-194.

562 Tanarhte, M., P. Hadjinicolaou., J. Lelieveld., 2012. Intercomparison of temperature and 563 precipitation data sets based on observations in the Mediterranean and the Middle East, J. Geophys. Res., 117, D12102, doi:10.1029/2011JD017293.

565 Tsvieli Y, Zangvil A. 2005. Synoptic climatological analysis of 'wet' and 'dry' Red Sea troughs 566 over Israel. Int. J. Climatol, 25(15), 1997-2015, doi:10.1002/joc.123. 
567 Tsvieli Y, Zangvil A. 2007. Synoptic climatological analysis of Red Sea trough and non-Red Sea 568 trough rain situations over Israel. Adv. Geosci., 12, 137-143.

569 Wang S, Huang J, He Y, Guan Y. 2014. Combined effects of the Pacific Decadal Oscillation and 570 571 El Niño- Southern Oscillation on Global Land Dry-Wet Changes. Sci. Rep., 4, 6651; DOI:10.1038/srep06651

572 Wei J, Su H, Yang ZL. 2015. Impact of moisture flux convergence and soil moisture on 573 precipitation: a case study for the southern United States with implications for the globe. 574 Climate Dynamics. DOI 10.1007/s00382-015-2593-2

575 Yatagai A, Kamiguchi K, Arakawa O, Hamada A, Yasutomi N, Kitoh A. 2012. Aphrodite 576 constructing a long-term daily gridded precipitation dataset for Asia based on a dense 577 network of rain gauges. Bull. Am. Meteorol. Soc., 93(9), 1401-1415, doi:10.1175/BAMS$578 \quad$ D-11-00122.1.

579 Yatagai A., Xie P, Alpert P., 2008. Development of a daily gridded precipitation data set for the 580 Middle East. Adv. Geosci., 12, 165-170. www.adv-geosci.net/12/165/2008/

581 Yesubabu V, Hari Prasad D, Sabique L, Srinivas CV, Hoteit I. 2016. Climatic features of the Red 582 Sea from a regional assimilative model. Int. J. Climatol., DOI: 10.1002/joc.4865

Zhiyu L, Xu H, Zhang W. 2015. Asymmetric Features for Two Types of ENSO. J. Meteor. Res., 584 29 (6): 896-916, doi: 10.1007/s13351-015-5044-4. 
585 Ziv B, Dayan U, Sharon D. 2005. A mid-winter, tropical extreme flood-producing storm in 586 southern Israel: Synoptic scale analysis. Meteorol. Atmos. Phys., 88(1-2), 53-63, 587 doi:10.1007/s00703-003-0054-7.

588 Zolina, O., A. Dufour, S. Gulev, and G. Stenchikov. 2017. Regional hydrological cycle over the 589 Red Sea in ERA-Interim. J. Hydrometeor., 18, 65-83, doi:10.1175/JHM-D-16-0048.1

590 
Figure captions:

592 Figure 1. Mean seasonal (October - January) winds (m/sec) at $10 \mathrm{~m}$ a) 35 years, b) El Niño, c) La Niña, 593 and d) El Niño - La Niña years between 1979-2015.

594 Figure 2. Mean seasonal (October - January) winds (m/sec) and geopotential (shaded, gpm) at $850 \mathrm{hPa}$. 595 a) 35 years, b) b) El Niño - Mean, c) La Niña - Mean, and d) El Niño - La Niña years between 1979-2015.

Figure 3. Mean seasonal (October - January) temperatures $\left({ }^{\circ} \mathrm{C}\right)$ at different levels. Right column is for 35 years mean, middle column is for El Niño - Mean, and left column is for La Niña - Mean years between 598 1979-2015. Top panel is for $925 \mathrm{hPa}$, middle panel is for $850 \mathrm{hPa}$ and bottom panel is for $700 \mathrm{hPa}$.

Figure 4. Mean seasonal (October - January) rainfall (mm/day) a) 35 years, and b) El Niño - La Niña 600 years between 1979-2015.

601 Figure 5. Mean daily rainfall (mm/day) averaged over $20^{\circ} \mathrm{N}-24^{\circ} \mathrm{N}$ latitude during October to January. a) 60235 years, b) neutral c) El Niño, and d) La Niña.

603 Figure 6. Mean daily rainfall ( $\mathrm{mm} /$ day) averaged over $37.5^{0} \mathrm{E}-39.5^{0} \mathrm{E}$ latitude during October to January. 604 a) 35 years, b) neutral c) El Niño, and d) La Niña.

605 Figure 7. Mean daily rainfall (mm/day) averaged over a) Eastern side $\left(18^{\circ} \mathrm{E}-24^{\circ} \mathrm{E} ; 34^{\circ} \mathrm{E}-36^{\circ} \mathrm{E}\right)$, b) 606 Western side $\left(18^{\circ} \mathrm{E}-24^{\circ} \mathrm{E} ; 40^{\circ} \mathrm{E}-42^{\circ} \mathrm{E}\right)$, c) El Niño - La Niña (west coast), and d) La Niña - El Niño (east 607 coast) of the Red Sea.

608 Figure 8. Mean seasonal accumulated rainfall $(\mathrm{mm})$ in winter months. a) Stations with rainfall higher in 609 El Niño years, b) Stations with rainfall higher in La Niña years, and c) Spatial distribution of station 610 rainfall both in El Niño (Red color bar) and La Niña (Blue color bar) years along with the terrain height 611 (m).

612 Figure 9. Mean seasonal (October - January) convective available potential energy (CAPE, J/Kg) a) 35 613 years, and b) El Niño - La Niña years between 1979-2015.

614 Figure 10. Difference of mean monthly Sea Surface Temperatures $\left({ }^{\circ} \mathrm{C}\right)$ along the Red Sea longitude axis. 615 a) El Niño - Mean, b) La Niña - Mean.

616 Figure 11. Mean seasonal (October - January) total column precipitable water vapor (g/kg). a) 35 years, 617 b) El Niño, c) La Niña, and d) El Niño - La Niña years between 1979-2015. 
618 Figure 12 . Mean seasonal (October - January) vertically integrated moisture $\left(x 10^{-6} \mathrm{~kg} \cdot \mathrm{m}^{-2} \cdot \mathrm{sec}^{-1}\right.$, shaded 619 convergence). a) 35 years, b) El Niño, c) La Niña, and d) El Niño - La Niña years between 1979-2015. The 620 arrows indicate the moisture transport vectors $\left(\mathrm{kg} \cdot \mathrm{m}^{-1} \cdot \mathrm{sec}^{-1}\right)$.

621 Figure 13. Correlation Coefficients of Multi Variant ENSO Index and to a) Total Column Precipitable 622 Water, and b) Vertically integrated moisture. Significance with more than $95 \%$ are presented with + 623 symbol.

624 Figure 14. Mean seasonal (October - January) evaporation (mm.day ${ }^{-1}$ ). a) 35 years, b) El Niño - Mean, c) 625 La Niña - Mean, and d) El Niño - La Niña years between 1979-2015.

626 Figure 15. Schematic presentation of the different synoptic scale features associated with RSCZ and 627 rainfall during (a) Normal, (b) El Niño, and (c) La Niña years. The direction of white line indicates the moisture transport pathways. Surface winds over the Red Sea are presented by red and blue arrows (thicker indicates stronger magnitudes). As in De Veries et al., (2013); (H) refers to High pressure system; 630 (A) to Arabian Anticyclone, (RST) to Red Sea Trough, (STJ) to Sub Tropical Jet, (3L) to Upper Level Trough, (RSCZ) to Red Sea Convergence Zone, and white color clouds to convective activity.

632 Figure S1. Mean seasonal (October - January) hydrological cycle of a) evaporation (mm.day ${ }^{-1}$ ), b) 633 precipitation $(\mathrm{mm} /$ day), c) evaporation - precipitation $(\mathrm{mm} /$ day), and d) vertically integrated moisture $(x$ $63410^{-6} \mathrm{~kg} \cdot \mathrm{m}^{-2} \cdot \mathrm{sec}^{-1}$, shaded convergence) between 1979-2015. The arrows indicate the moisture transport 635 vectors $\left(\mathrm{kg} \cdot \mathrm{m}^{-1} \cdot \mathrm{sec}^{-1}\right)$. The right panel is (35 year mean), middle panel is (El Niño - Mean) and left panel is 636 (La Niña - Mean).

637 Figure 2s. Mean seasonal (October - January) winds (m/sec) and geopotential (shaded, gpm) at $850 \mathrm{hPa}$. 638 a) 110 years, b) b) El Niño - Mean, c) La Niña - Mean, and d) El Niño - La Niña years between 19016392010. 
a) Mean

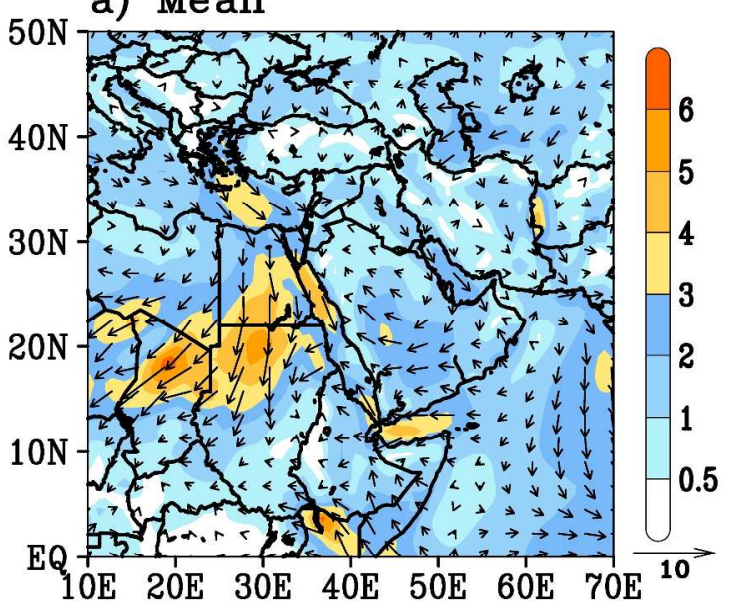

c) La Nina

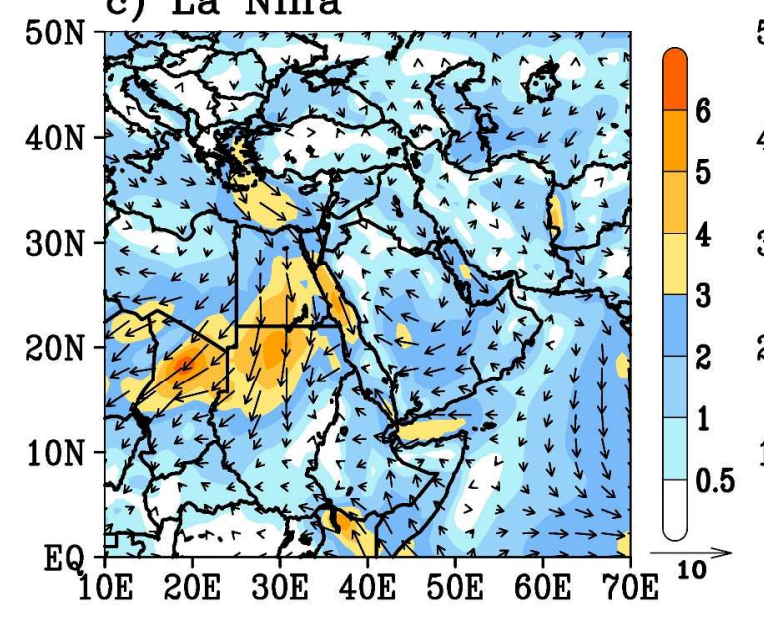

b) El Nino

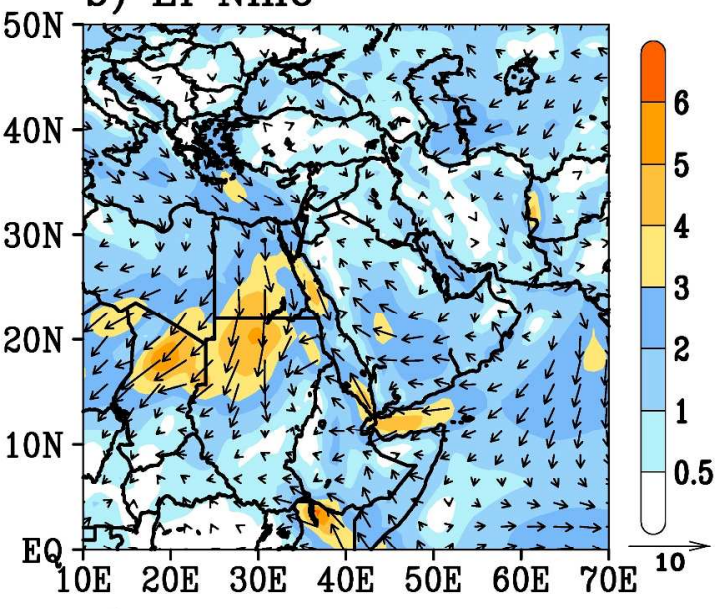

d) El Nino - La Nina

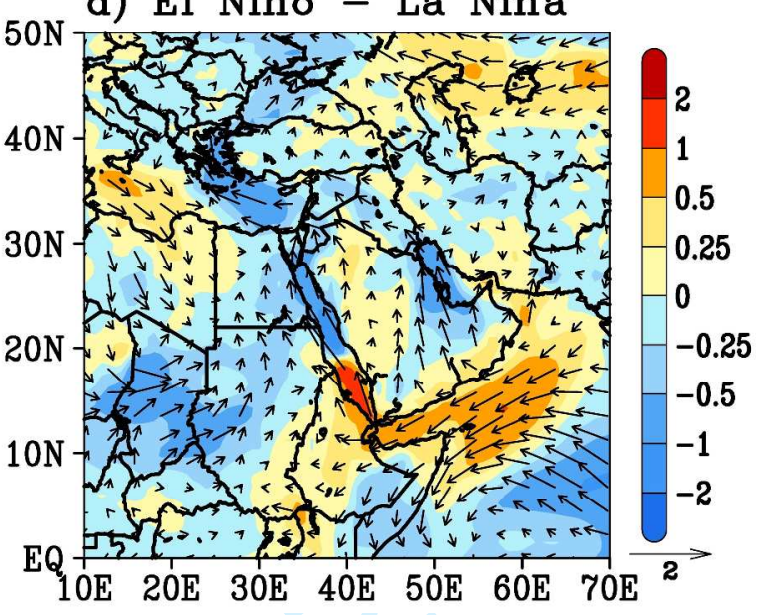

649

Figure 1. Mean seasonal (October - January) winds (m/sec) at $10 \mathrm{~m}$ a) 35 years, b) El Niño, c) La Niña, 650 and d) El Niño - La Niña years between 1979-2015.

651

652

653

654 
a) Mean

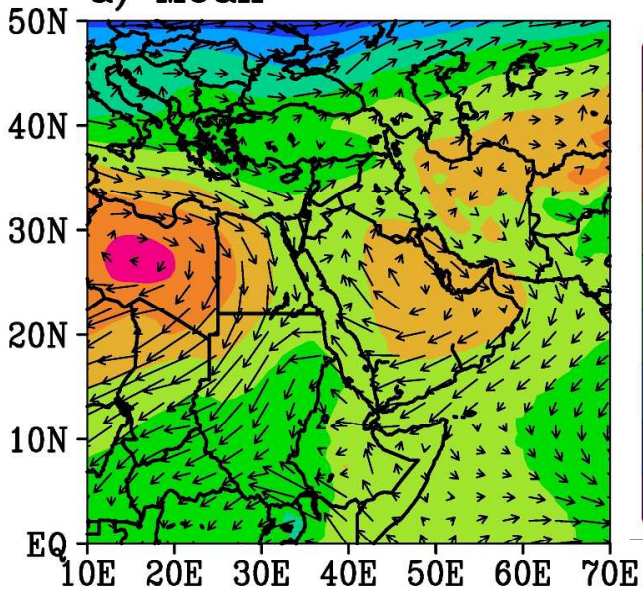

c) La Nina - Mean

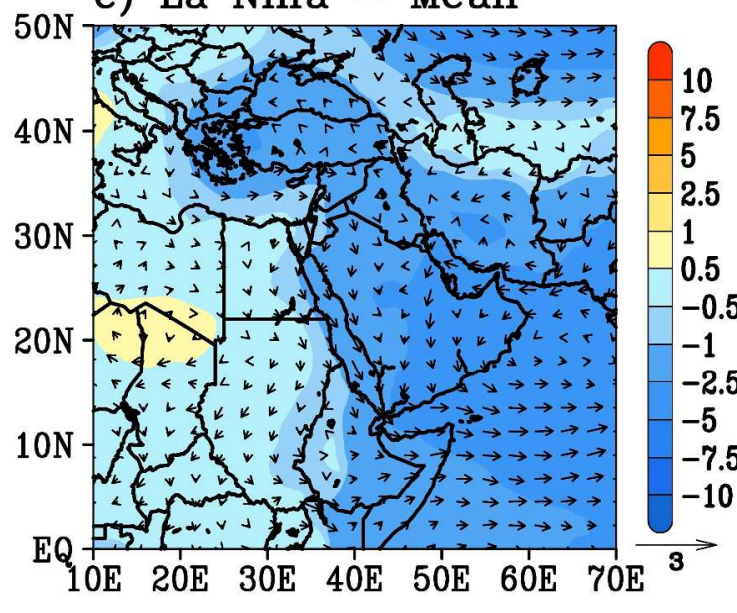

b) El Nino - Mean

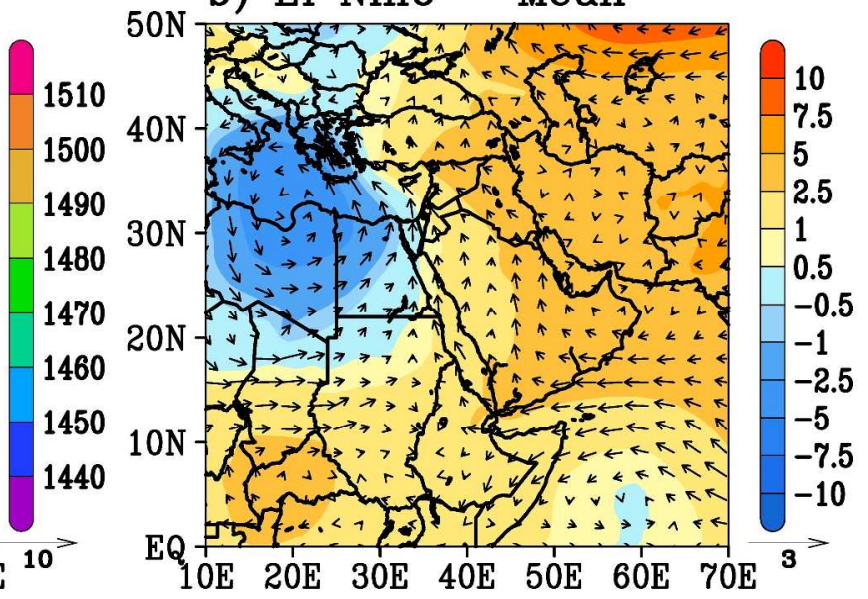

d) El Nino - La Nina

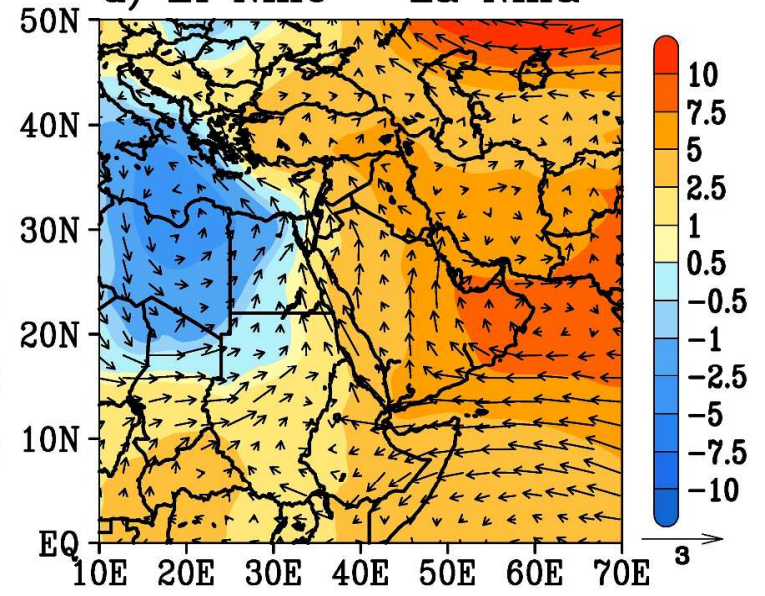

Figure 2. Mean seasonal (October - January) winds (m/sec) and geopotential (shaded, gpm) at $850 \mathrm{hPa}$.

659 a) 35 years, b) b) El Niño - Mean, c) La Niña - Mean, and d) El Niño - La Niña years between 1979-2015.

660

661

662

663

664 

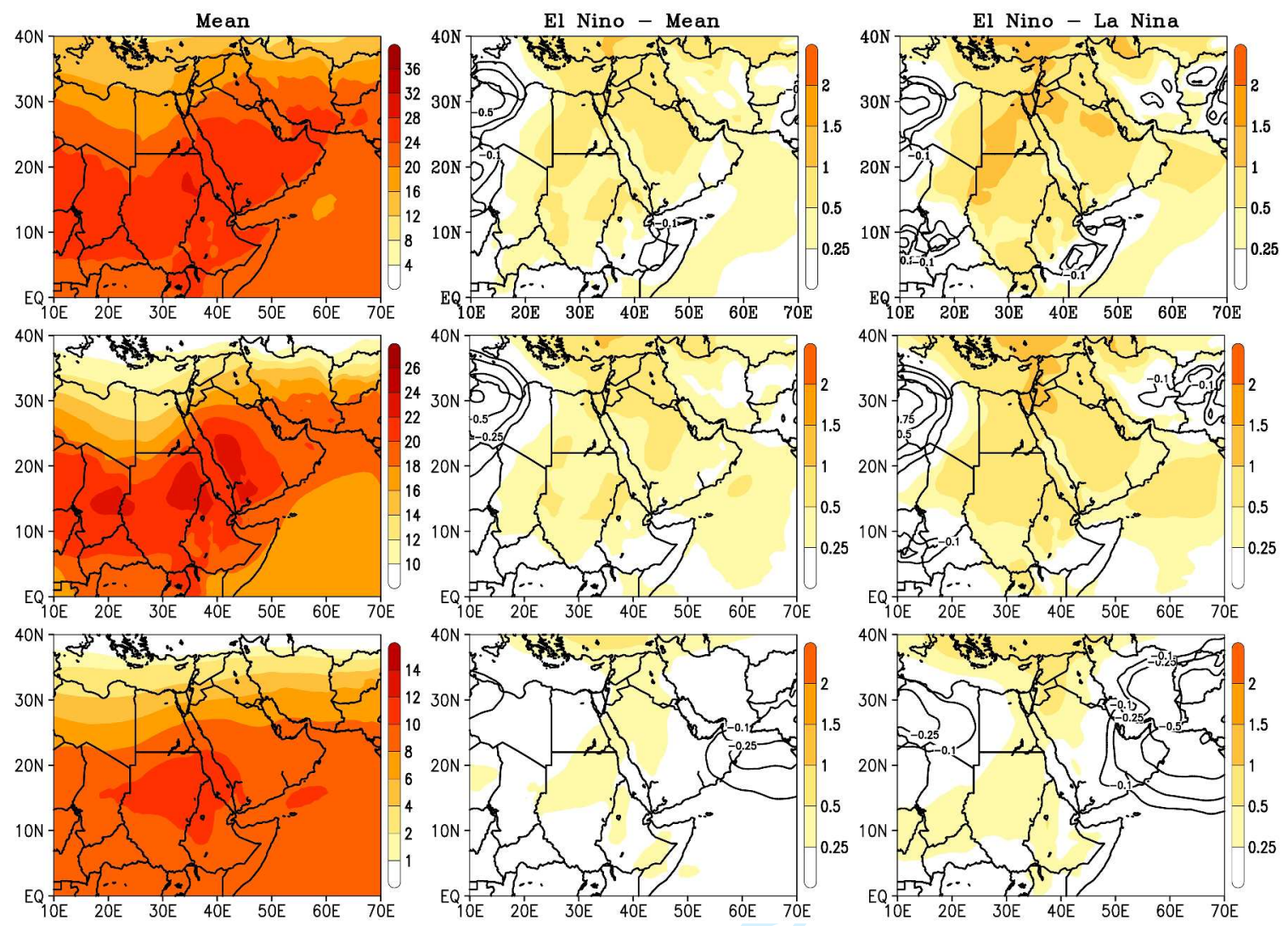

Figure 3. Mean seasonal (October - January) temperatures $\left({ }^{\circ} \mathrm{C}\right)$ at different levels. Right column is for 35 668 years mean, middle column is for El Niño - Mean, and left column is for La Niña - Mean years between 1979-2015. Top panel is for $925 \mathrm{hPa}$, middle panel is for $850 \mathrm{hPa}$ and bottom panel is for $700 \mathrm{hPa}$. 
677

678

679

680

681

682

683

684

685

686

687

688

689

690

691

692

693 b) El Nino - La Nina
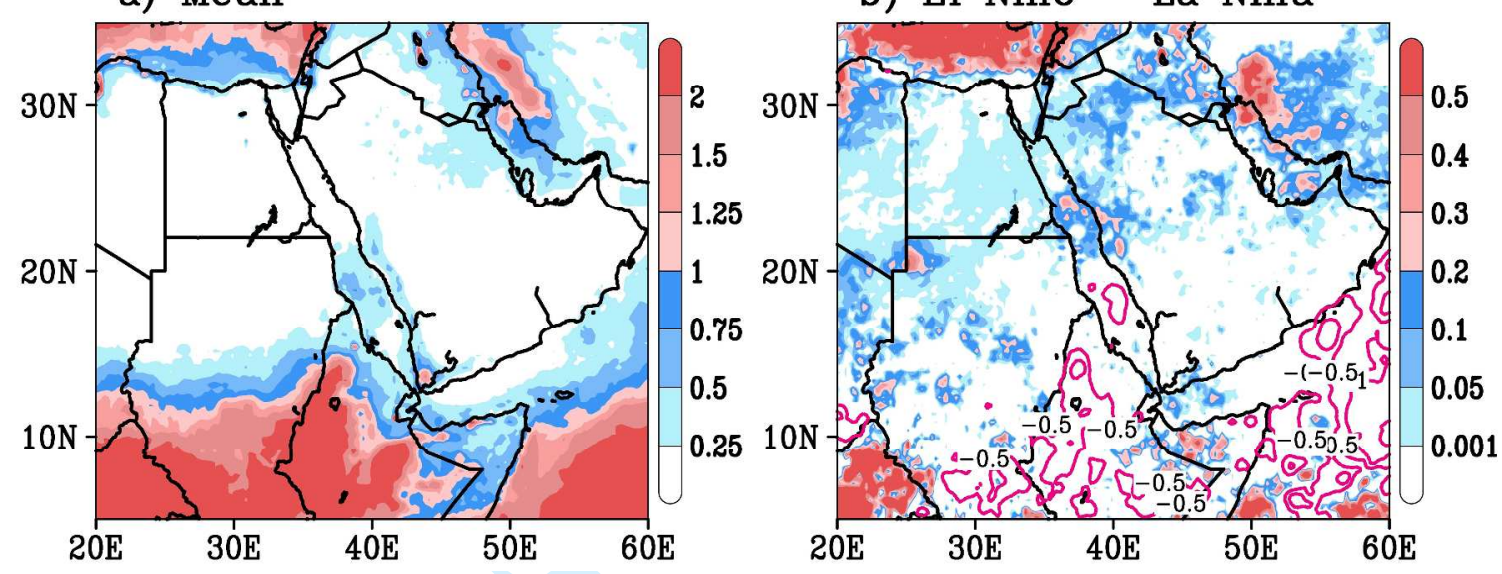

Figure 4. Mean seasonal (October - January) rainfall (mm/day) a) 35 years, and b) El Niño - La Niña years between 1979-2015. 
694

a) Mean

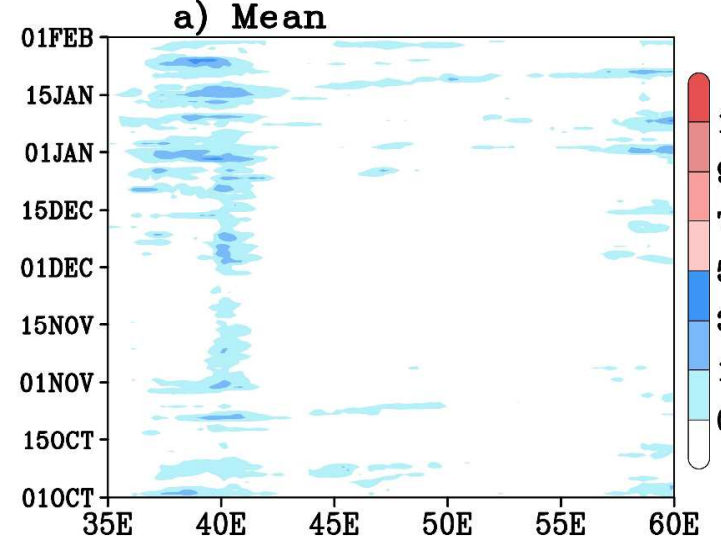

c) El Nino

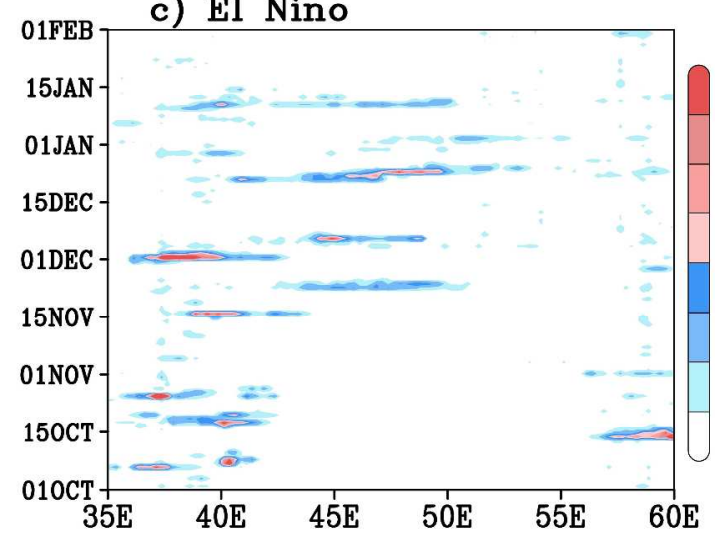

b) Neutral

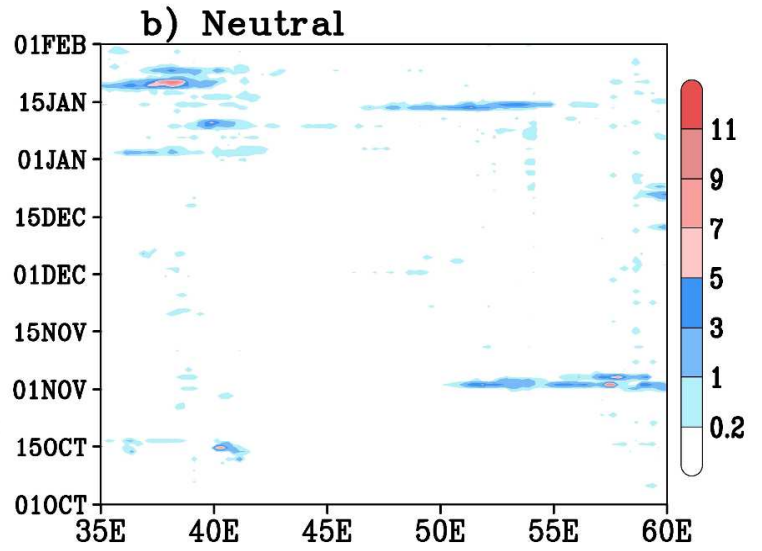

d) La Nina

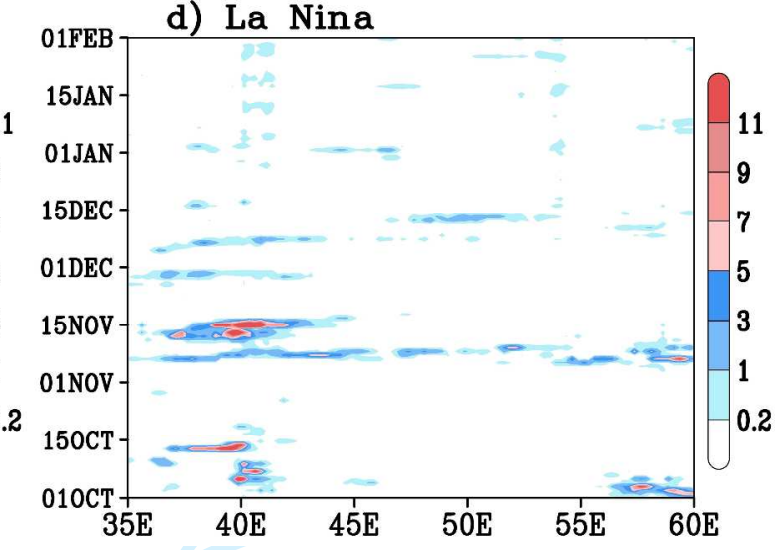

696 Figure 5. Mean daily rainfall (mm/day) averaged over $20^{\circ} \mathrm{N}-24^{0} \mathrm{~N}$ latitude during October to January. a) 69735 years, b) neutral c) El Niño, and d) La Niña. 

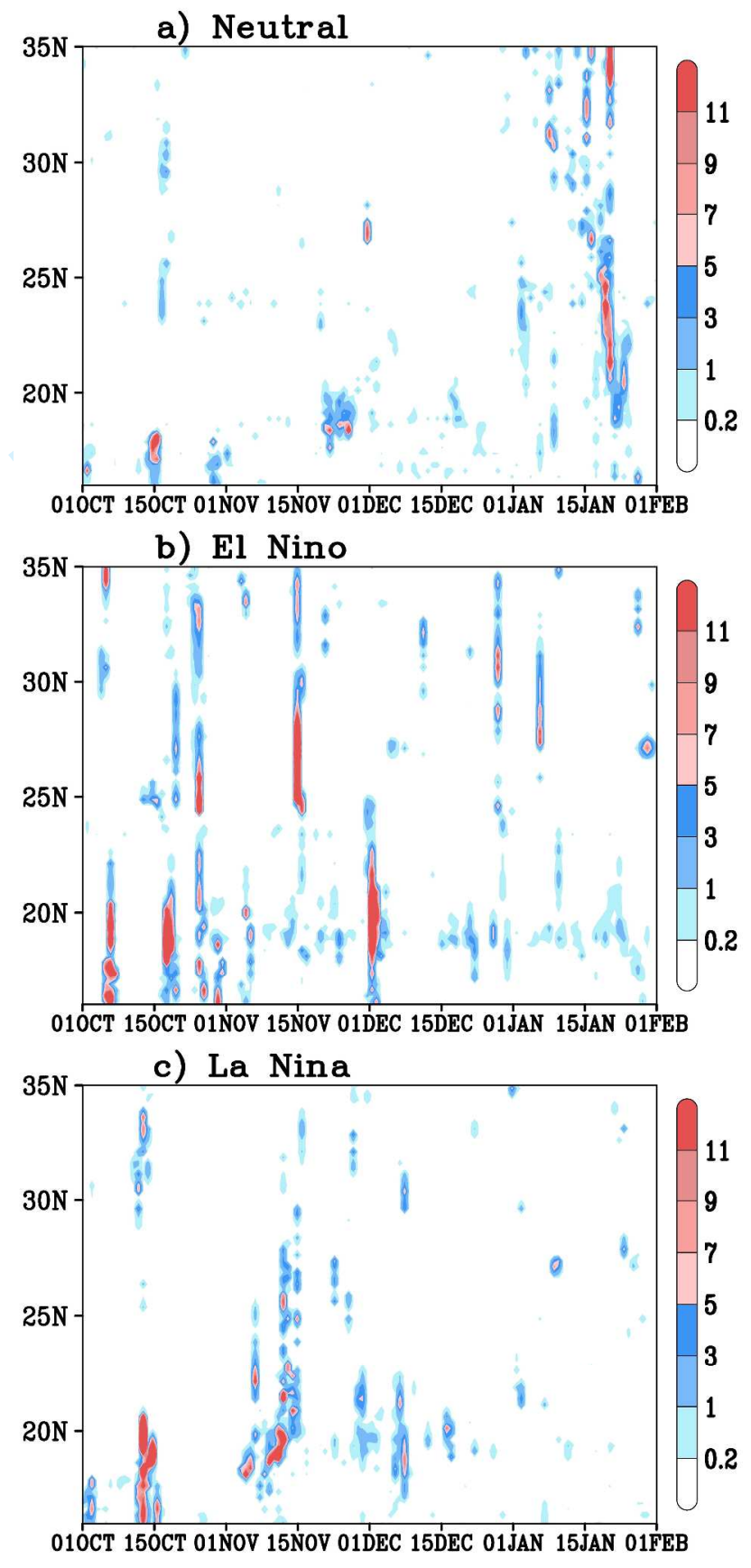

Figure 6. Mean daily rainfall ( $\mathrm{mm} /$ day) averaged over $37.5^{\circ} \mathrm{E}-39.5^{\circ} \mathrm{E}$ latitude during October to January.

708 a) 35 years, b) neutral c) El Niño, and d) La Niña. 

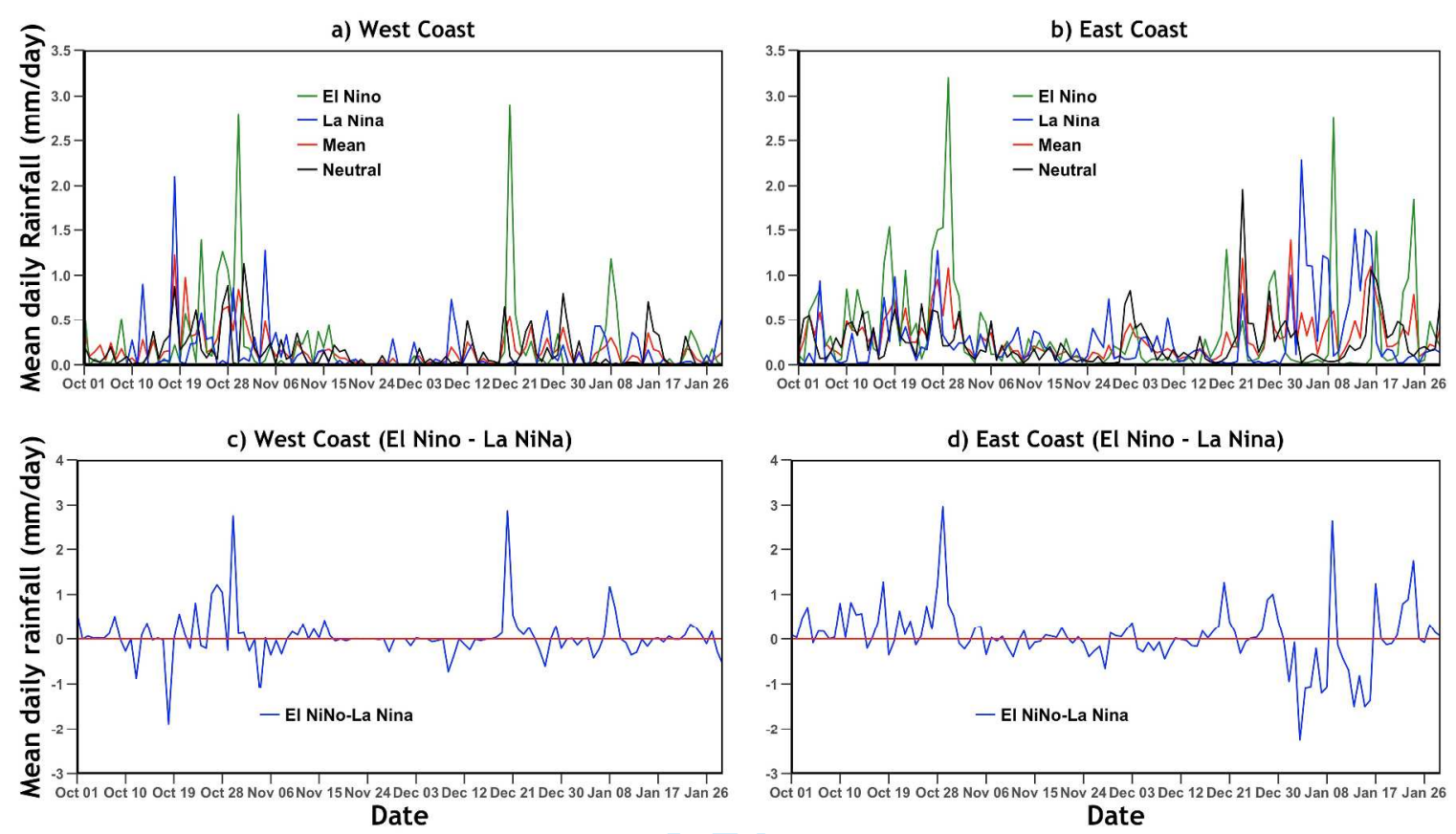

711 Figure 7. Mean daily rainfall (mm/day) averaged over a) Eastern side $\left(18^{\circ} \mathrm{E}-24^{\circ} \mathrm{E} ; 34^{\circ} \mathrm{E}-36^{0} \mathrm{E}\right)$, b)

712 Western side $\left(18^{\circ} \mathrm{E}-24^{\circ} \mathrm{E} ; 40^{\circ} \mathrm{E}-42^{\circ} \mathrm{E}\right)$, c) El Niño - La Niña (west coast), and d) La Niña - El Niño (east 713 coast) of the Red Sea. 

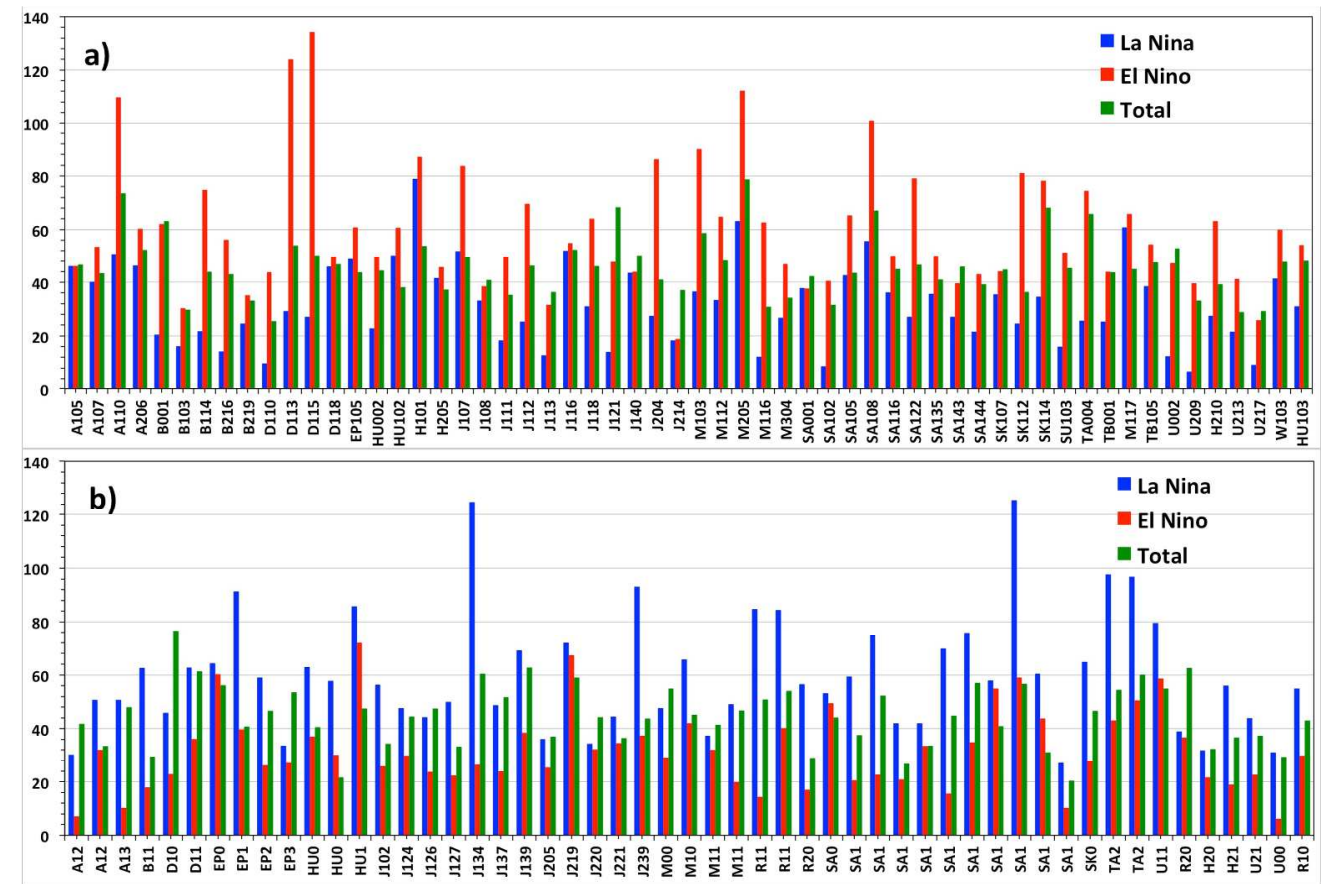

734

735

736

737

738

739

740

741

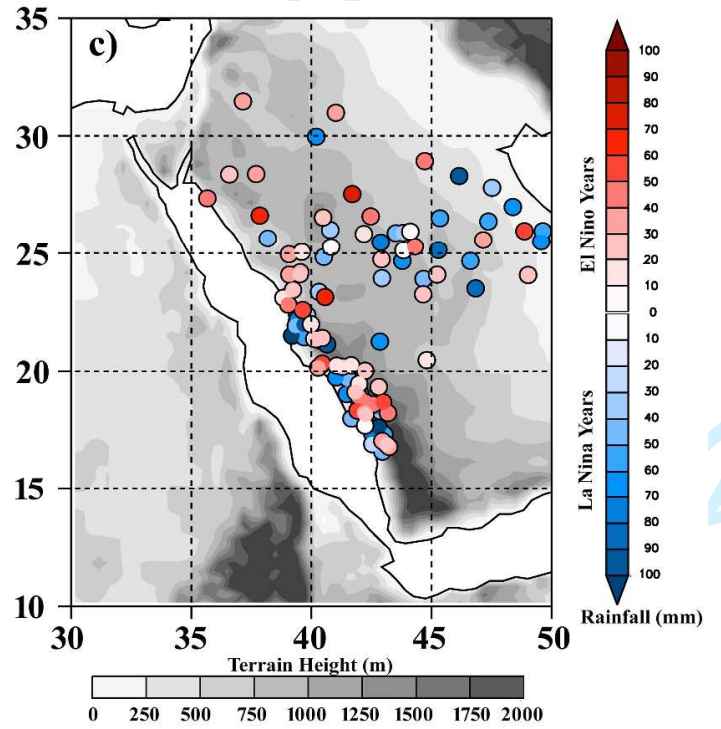

Figure 8. Mean seasonal accumulated rainfall $(\mathrm{mm})$ in winter months. a) Stations with rainfall higher in El Niño years, b) Stations with rainfall higher in La Niña years, and c) Spatial distribution of station

745 rainfall both in El Niño (Red color bar) and La Niña (Blue color bar) years along with the terrain height 746 (m). 
a) Mean

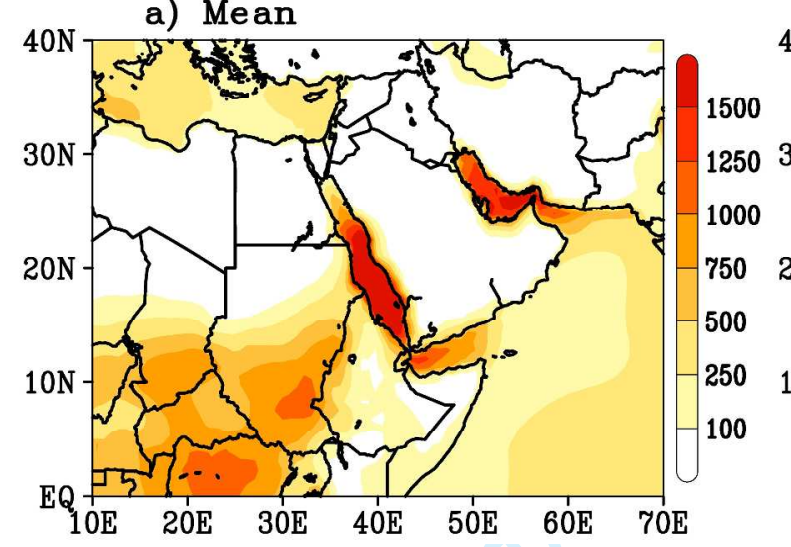

b) El Nino - La Nina

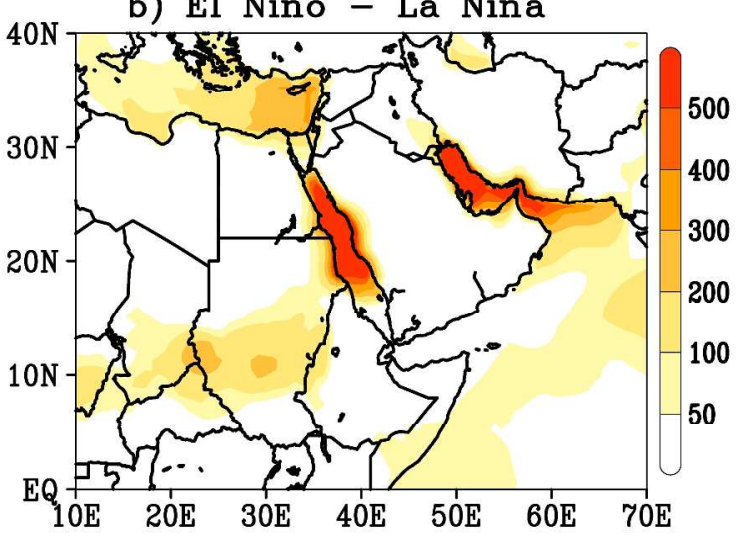

Figure 9. Mean seasonal (October - January) convective available potential energy (CAPE, J/Kg) a) 35 years, and b) El Niño - La Niña years between 1979-2015.

751

752

753

754

755

756

757

758

759

760

761

762

763

764 


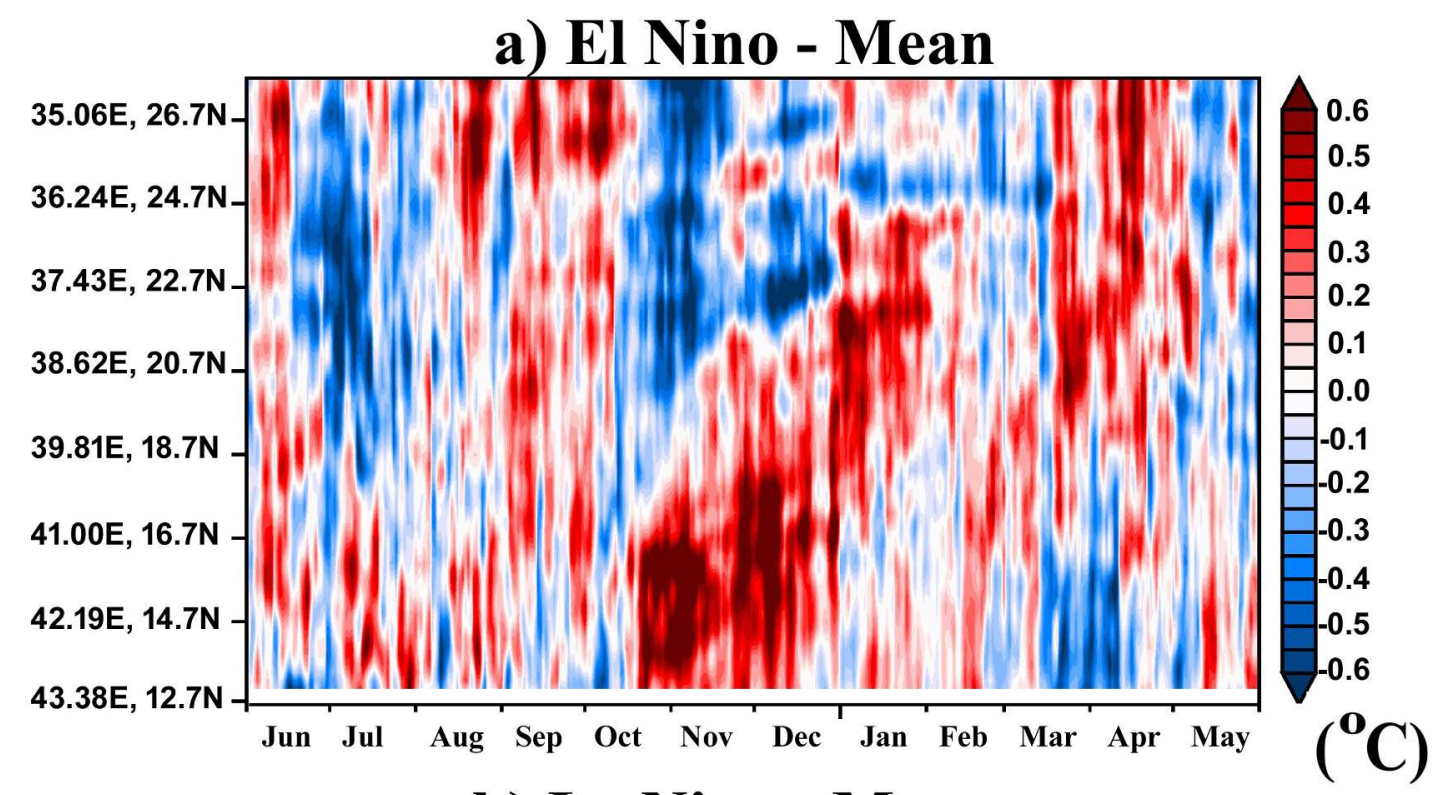

b) La Nina - Mean

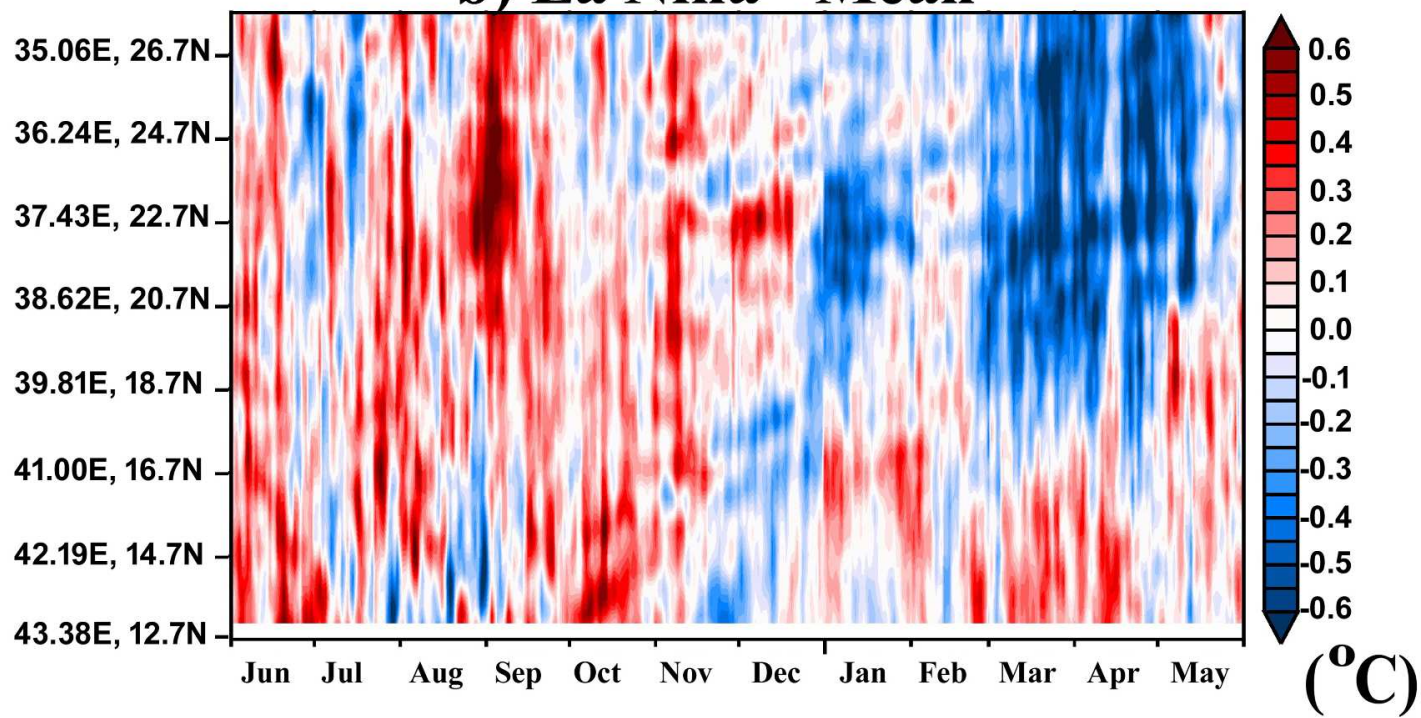

767 Figure 10. Difference of mean monthly Sea Surface Temperatures $\left({ }^{\circ} \mathrm{C}\right)$ along the Red Sea longitude axis.

768 a) El Niño - Mean, b) La Niña - Mean. 
a) Mean

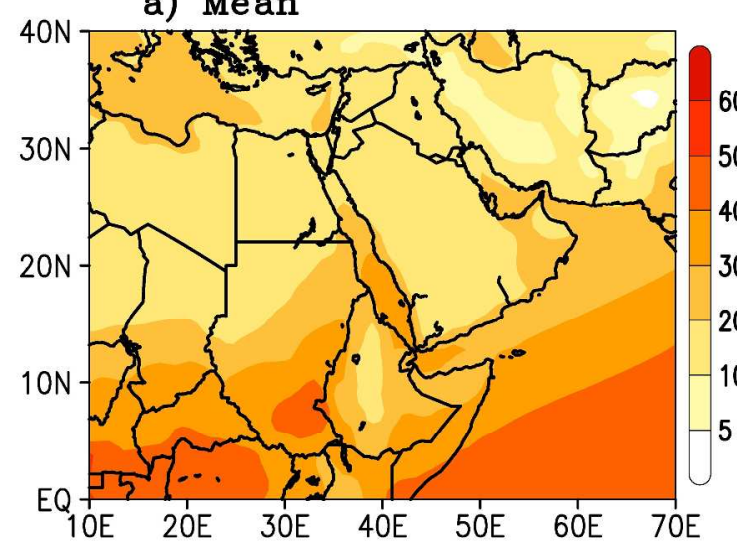

c) La Nina

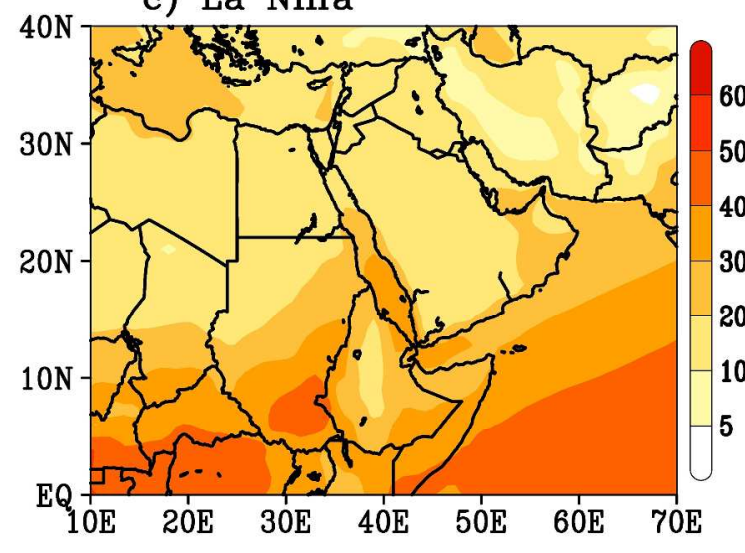

b) El Nino

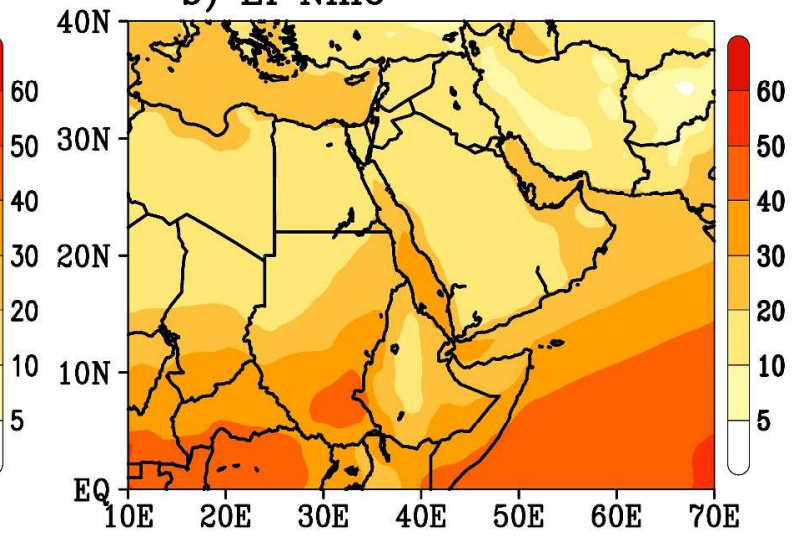

d) El Nino - La Nina

Figure 11. Mean seasonal (October - January) total column precipitable water vapor (g/kg). a) 35 years,

774 b) El Niño, c) La Niña, and d) El Niño - La Niña years between 1979-2015.

775

776

777 
a) Mean

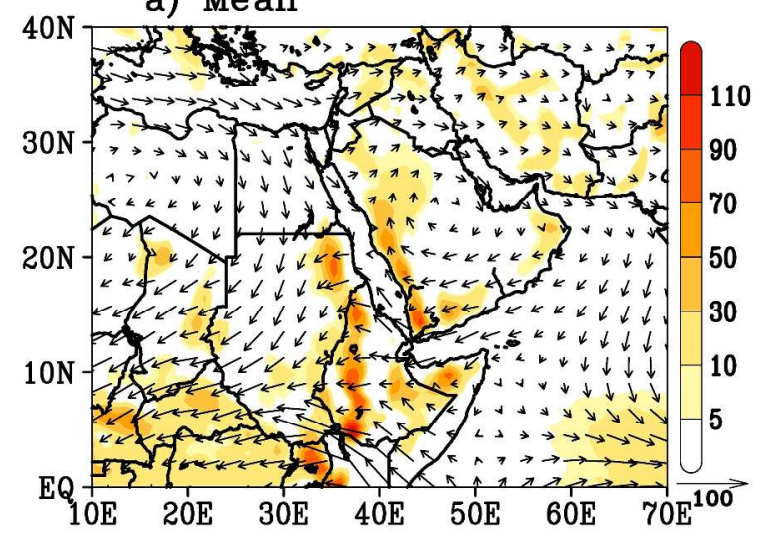

c) La Nina

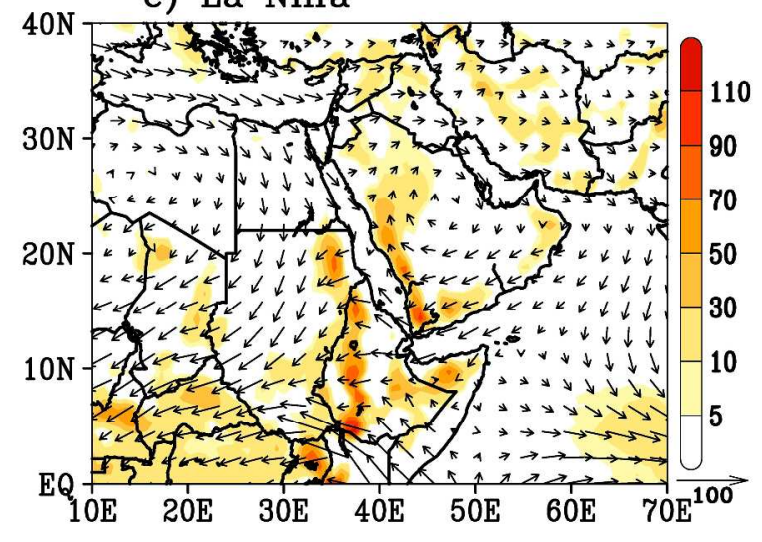

b) El Nino

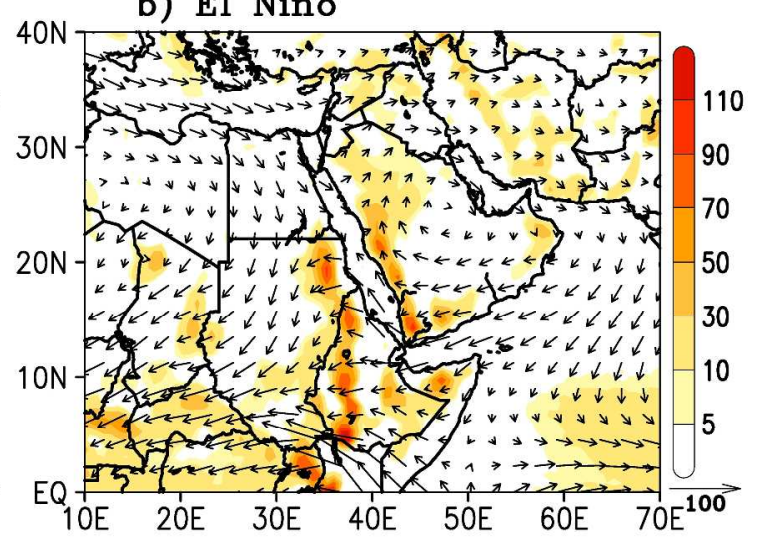

d) El Nino - La Nina

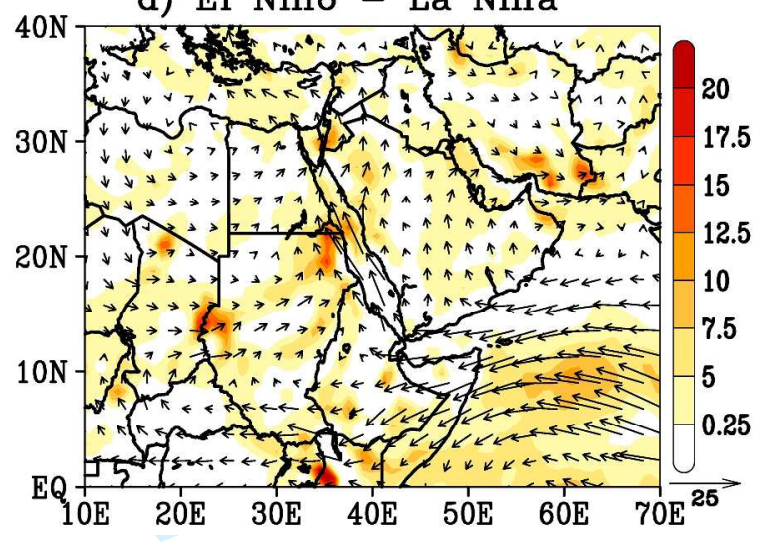

784

785

786

787

788

789

790

791

792

Figure 12. Mean seasonal (October - January) vertically integrated moisture $\left(x 10^{-6} \mathrm{~kg} \cdot \mathrm{m}^{-2} \cdot \mathrm{sec}^{-1}\right.$, shaded convergence). a) 35 years, b) El Niño, c) La Niña, and d) El Niño - La Niña years between 1979-2015. The arrows indicate the moisture transport vectors $\left(\mathrm{kg} \cdot \mathrm{m}^{-1} \cdot \mathrm{sec}^{-1}\right)$.

2



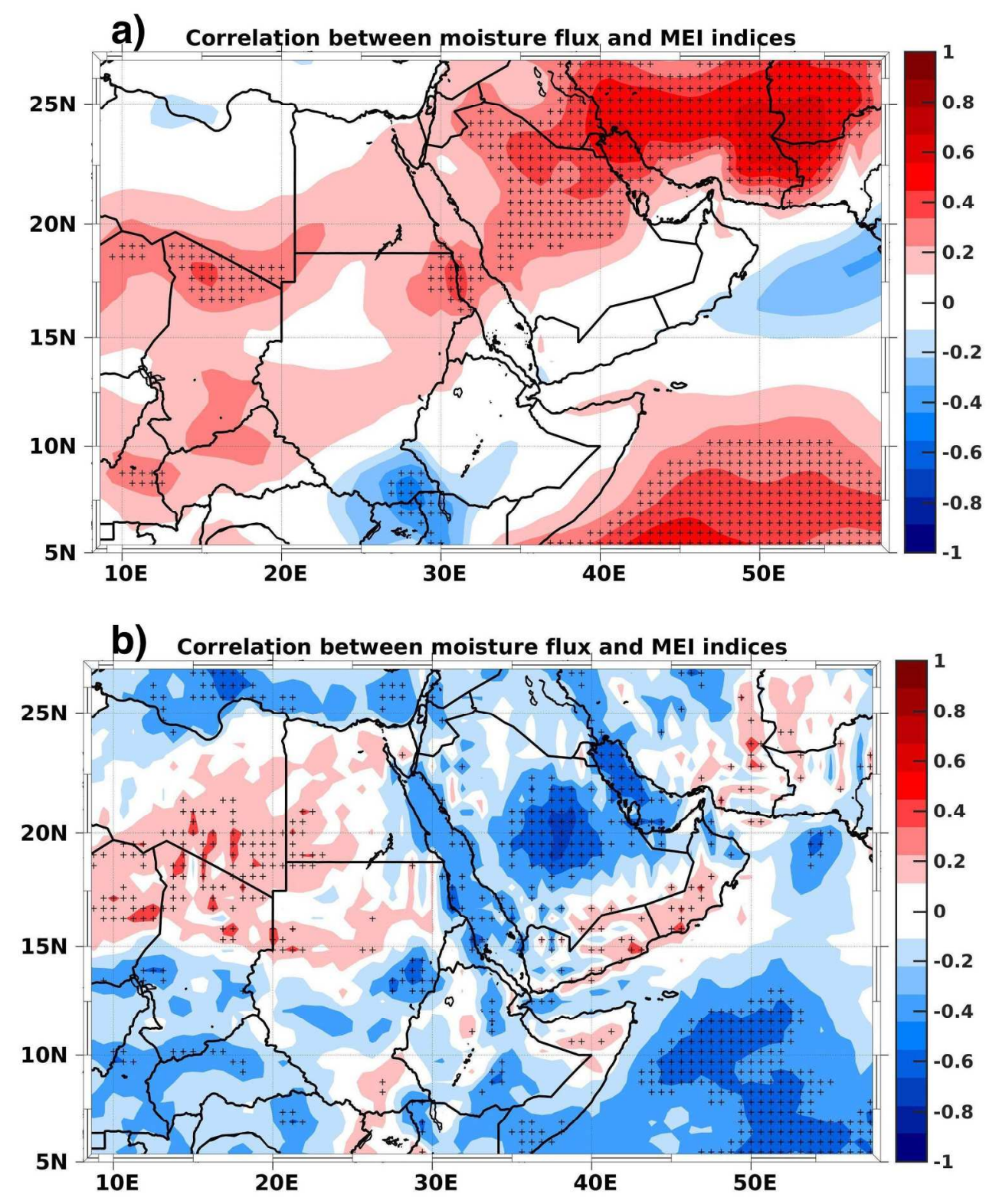

Figure 13. Correlation Coefficients of Multi Variant ENSO Index and to a) Total Column Precipitable Water, and b) Vertically integrated moisture. Significance with more than $95 \%$ are presented with + 797 symbol. 
a) Mean

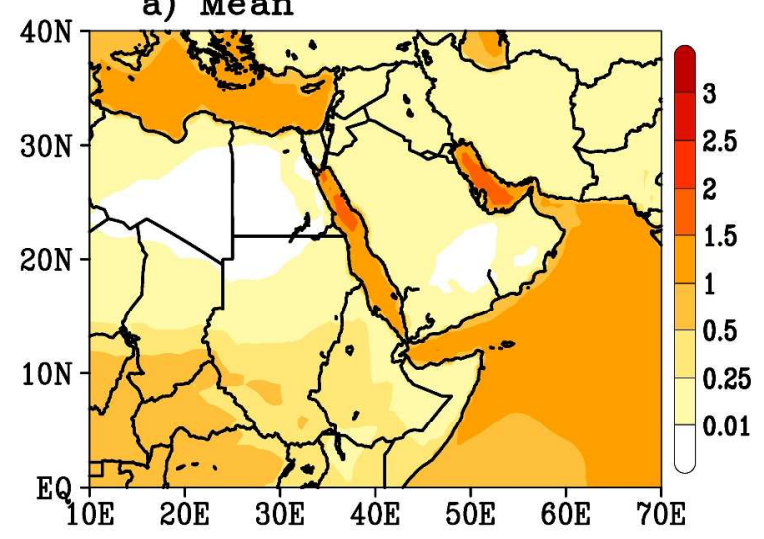

c) La Nina - Mean

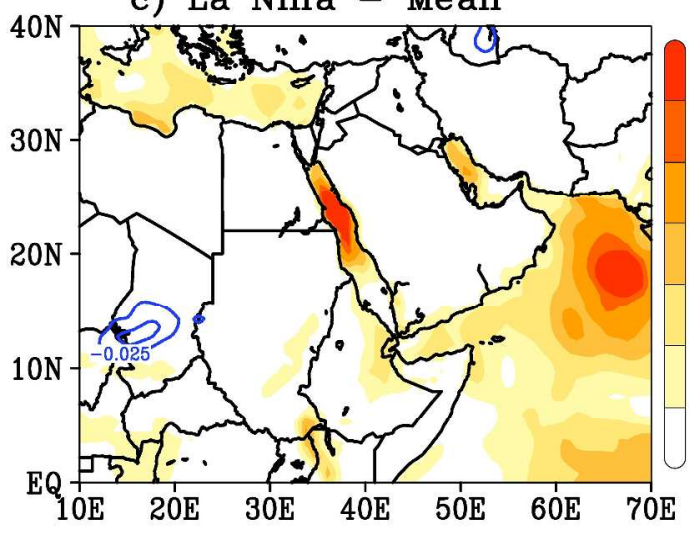

b) El Nino - Mean

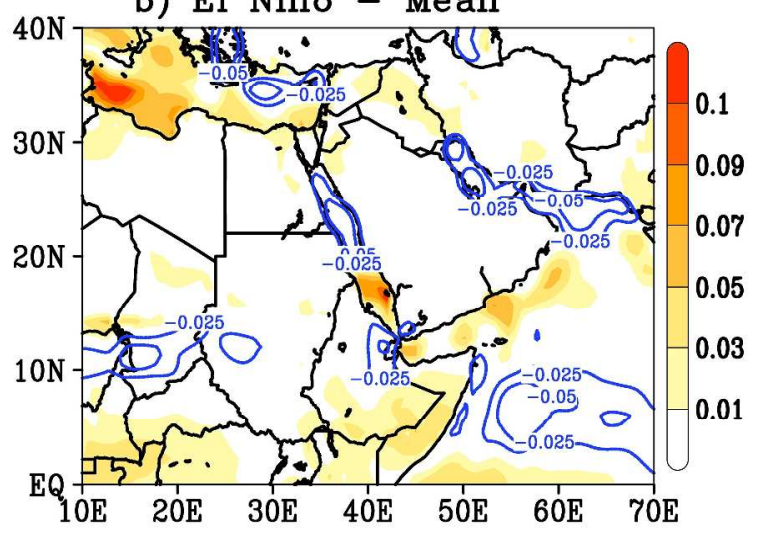

d) El Nino - La Nina

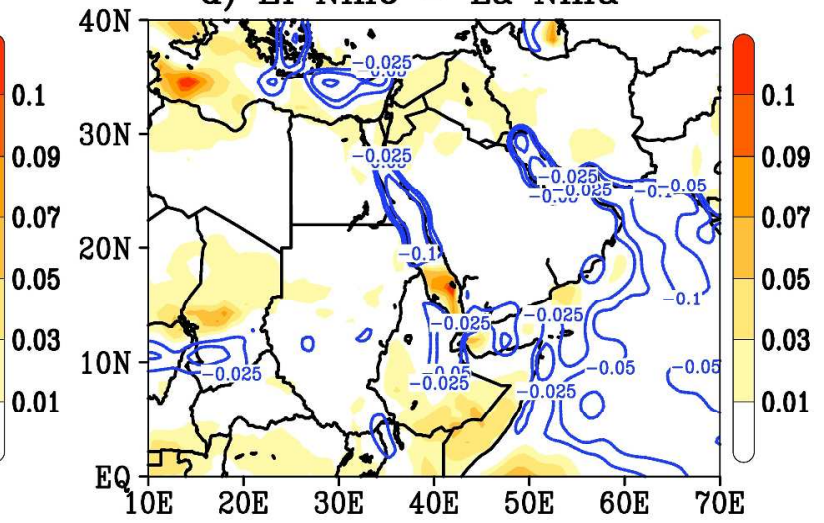

801

Figure 14. Mean seasonal (October - January) evaporation (mm.day ${ }^{-1}$ ). a) 35 years, b) El Niño - Mean, c)

802 La Niña - Mean, and d) El Niño - La Niña years between 1979-2015.

803

804

805

806

807

808 

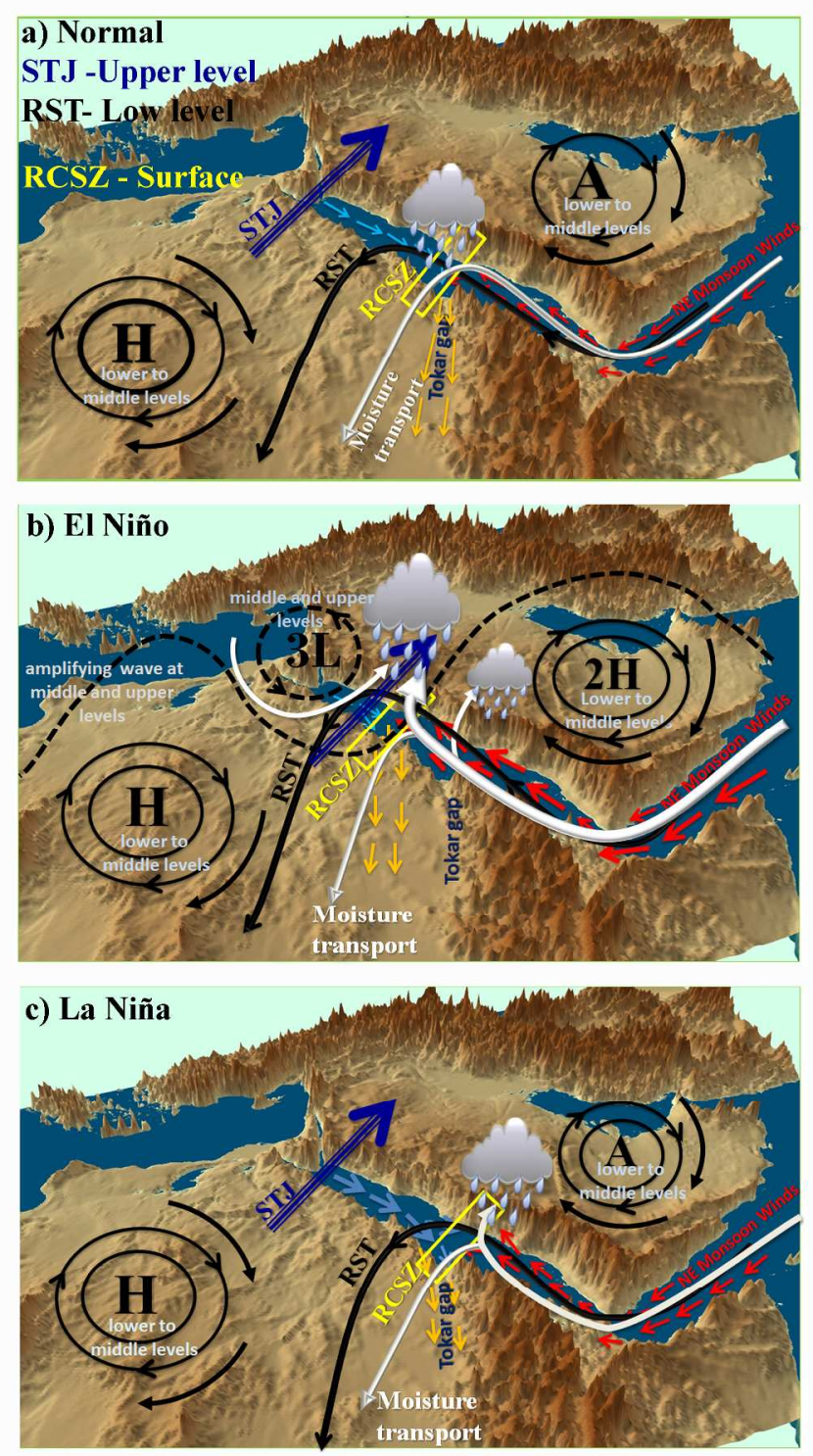

812 Figure 15. Schematic presentation of the different synoptic scale features associated with RSCZ and 813 rainfall during (a) Normal, (b) El Niño, and (c) La Niña years. The direction of white line indicates the 814 moisture transport pathways. Surface winds over the Red Sea are presented by red and blue arrows 815 (thicker indicates stronger magnitudes). As in De Veries et al., (2013); (H) refers to High pressure system; 816 (A) to Arabian Anticyclone, (RST) to Red Sea Trough, (STJ) to Sub Tropical Jet, (3L) to Upper Level 817 Trough, (RSCZ) to Red Sea Convergence Zone, and white color clouds to convective activity. 

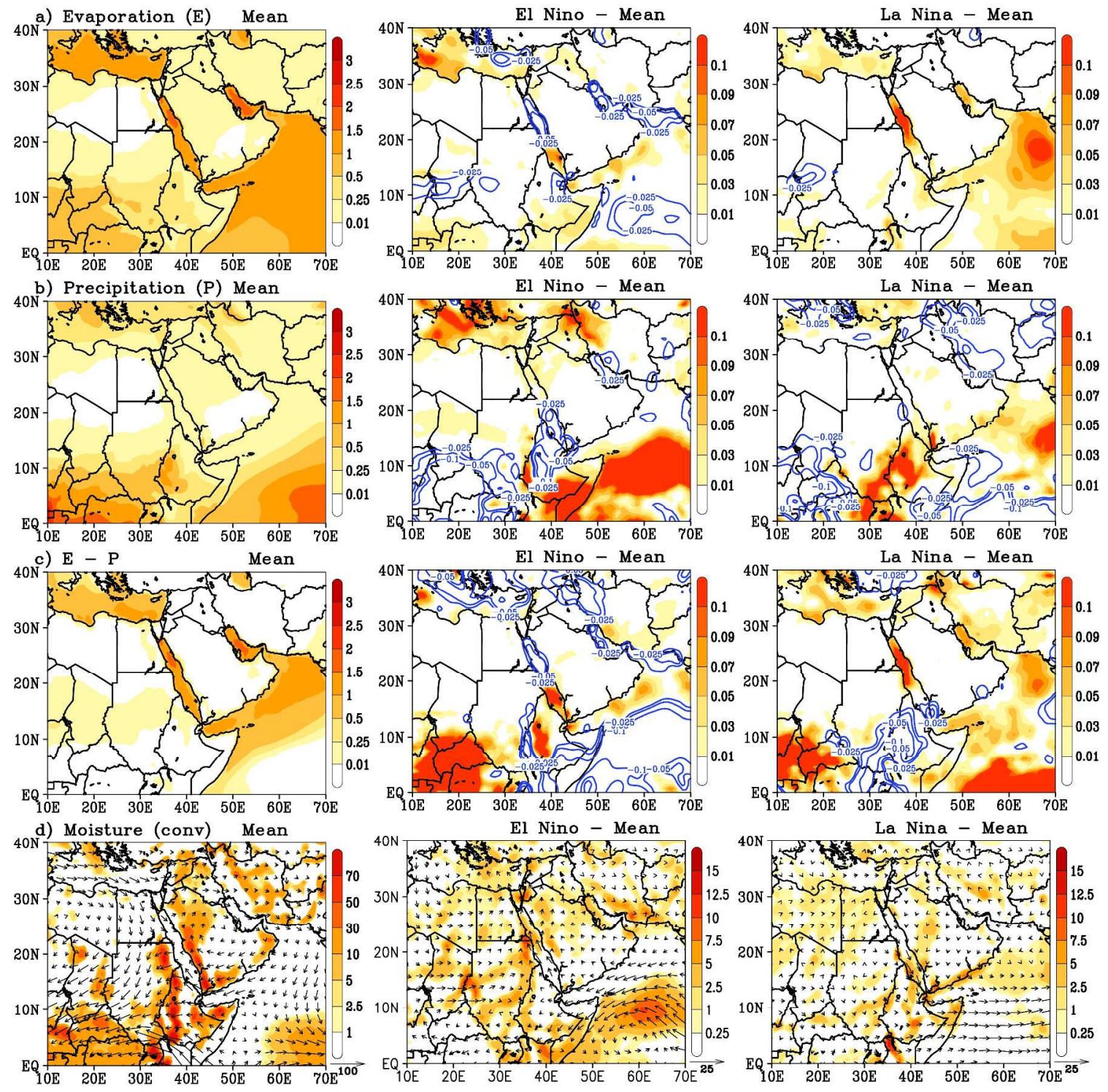

Figure S1. Mean seasonal (October - January) hydrological cycle of a) evaporation (mm.day ${ }^{-1}$ ), b) precipitation $(\mathrm{mm} /$ day), $\mathrm{c}$ ) evaporation - precipitation $(\mathrm{mm} /$ day), and $\mathrm{d})$ vertically integrated moisture $(\mathrm{x}$ $10^{-6} \mathrm{~kg} \cdot \mathrm{m}^{-2} \cdot \mathrm{sec}^{-1}$, shaded convergence) between 1979-2015. The arrows indicate the moisture transport 823 vectors $\left(\mathrm{kg} \cdot \mathrm{m}^{-1} \cdot \mathrm{sec}^{-1}\right)$. The right panel is (35 year mean), middle panel is (El Niño - Mean) and left panel is 824 (La Niña-Mean). 
a) Mean

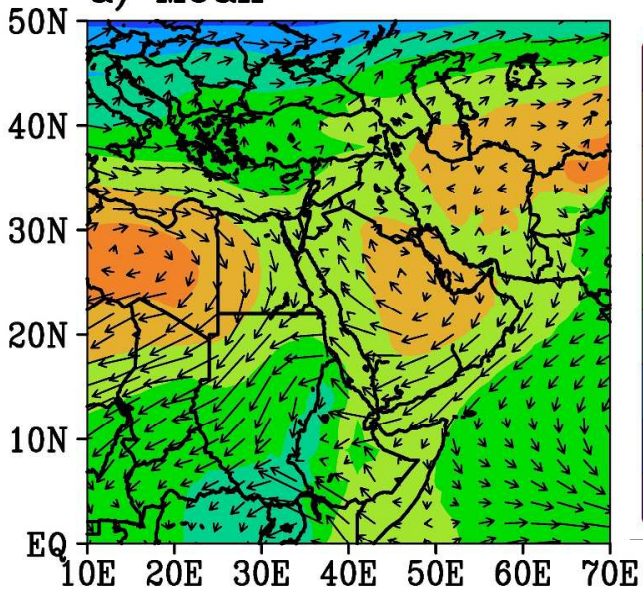

c) La Nina - Mean

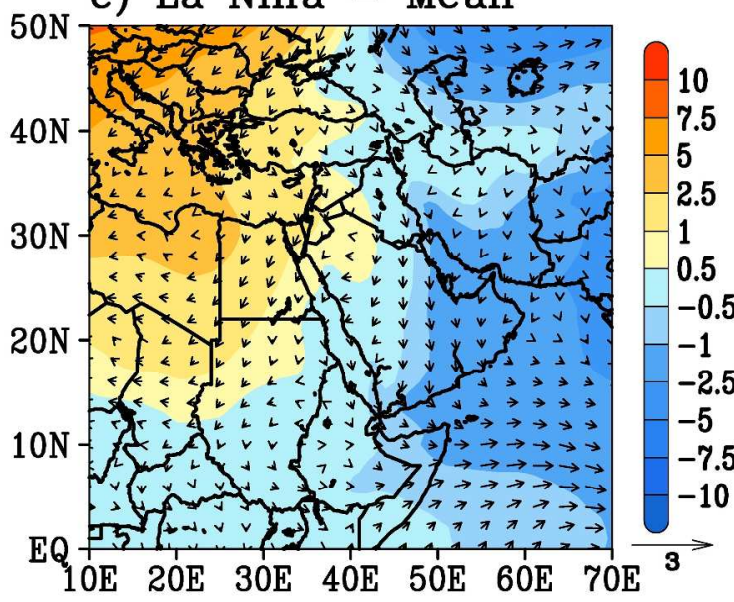

b) El Nina - Mean

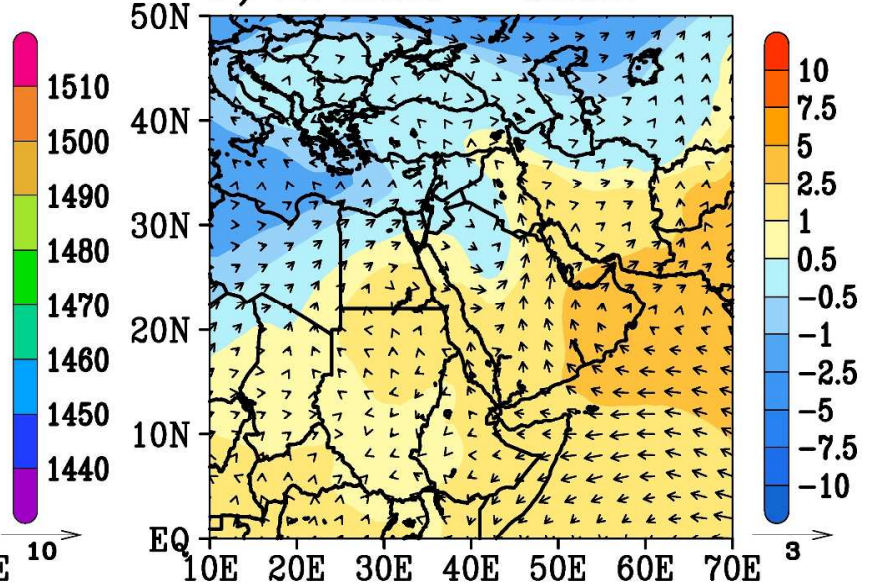

d) El Nina - La Nina

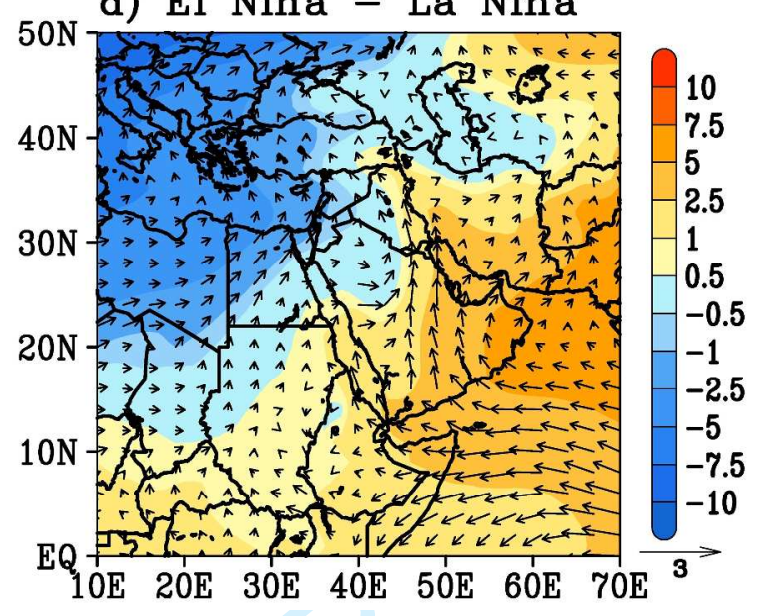

828 Figure 2s. Mean seasonal (October - January) winds (m/sec) and geopotential (shaded, gpm) at $850 \mathrm{hPa}$.

829 a) 110 years, b) b) El Niño - Mean, c) La Niña - Mean, and d) El Niño - La Niña years between 19018302010. 